\begin{abstract}
UNIVERSIDADE DE SÃO PAULO
FACULDADE DE FILOSOFIA, LETRAS E CIÊNCIAS HUMANAS

DEPARTAMENTO DE LETRAS CLÁSSICAS E VERNÁCULAS

PROGRAMA DE PÓS-GRADUAÇÃO EM ESTUDOS COMPARADOS DE LITERATURAS DE LÍNGUA PORTUGUESA
\end{abstract}

ÂNGELA RAPOSO DE MEDEIROS GOLDSTEIN

A REPRESENTAÇÃO DO ORIENTE NA OBRA POÉTICA DE ALBERTO OSÓRIO DE CASTRO

São Paulo

2012 


\author{
UNIVERSIDADE DE SÃO PAULO \\ FACULDADE DE FILOSOFIA, LETRAS E CIÊNCIAS HUMANAS \\ DEPARTAMENTO DE LETRAS CLÁSSICAS E VERNÁCULAS \\ PROGRAMA DE PÓS-GRADUAÇÃO EM ESTUDOS COMPARADOS DE \\ LITERATURAS DE LÍNGUA PORTUGUESA
}

\title{
A REPRESENTAÇÃO DO ORIENTE NA OBRA POÉTICA DE ALBERTO OSÓRIO DE CASTRO
}

\author{
Ângela Raposo de Medeiros Goldstein \\ Dissertação apresentada ao Programa \\ de Pós-Graduação em Estudos \\ Comparados de Literaturas de Língua \\ Portuguesa do Departamento de Letras \\ Clássicas e Vernáculas da Faculdade de \\ Filosofia, Letras e Ciências Humanas da \\ Universidade de São Paulo para a obtenção \\ do título de Mestre em Letras
}

Orientador: Prof. Dr. Hélder Garmes

São Paulo

2012 
A Antonio, Roseana e Marina, por tudo e sempre 


\section{Agradecimentos}

A Hélder Garmes, pela orientação, por toda ajuda, dedicação e apoio.

A Fátima Bueno e Lílian Jacoto pelas observações feitas na banca de qualificação deste trabalho.

A Fatima Mornas pela calorosa acolhida em Portugal.

A meu pai, Marcelo, por ter possibilitado as viagens necessárias para a realização da pesquisa. A minha avó e tios, pelo carinho que sempre me dedicaram.

A Carina, pela grande ajuda com as traduções necessárias e muito mais.

A minha mãe, Marta. 
"This notion of East and West is bizarre, the Earth is round and we are always East or West of somebody else."

Marjane Satrapi.

\section{Resumo}

O presente trabalho tem por objetivo averiguar como o mito do Oriente aparece na obra poética de Alberto Osório de Castro (1868 - 1946). Seu eixo central é o diálogo que seus poemas estabelecem com os temas e as formas da tradição oriental, em especial a indiana. Com isso, pretende-se delinear o orientalista que se encontra na obra do poeta português, partindo do pressuposto de que Osório de Castro inventa ali um Oriente. Busca-se averiguar a especificidade dessa invenção, identificando suas estratégias e possíveis intenções.

Palavras-chave: Oriente, Literatura Indo-Portuguesa, Simbolismo. 


\section{Abstract}

The present work aims to investigate how the Orient is represented in the poetic works of Alberto Osório de Castro (1868 - 1946). Its main axis is the dialog established between his poems and the topics and poetic forms found in the eastern tradition, especially in the Indian. This is intended in order to outline the Orientalist that can be found in the works of the Portuguese poet, assuming that Osório de Castro creates his own Orient. We seek to ascertain the specificity of this creation, identifying his strategies and possible intentions.

Keywords: Oriente, Indo-Portuguese Literature, Simbolism.

\section{Sumário}

Introdução.

8

Capítulo 1 - Acerca do autor, seu tempo e sua

obra... 10

Capítulo 2 - A questão

estética...... 
Capítulo 3 - A representação do Oriente e outros temas na obra de Alberto Osório de Castro.

3.1 Oriente como mito e não

tema

3.2 Análise do

Poema "Sati". 57

Considerações

finais...... .83

Poema "Sâti".

.8

9

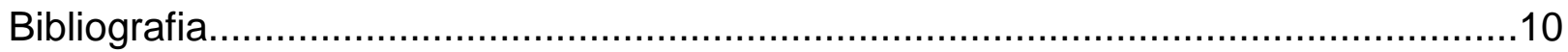

8 


\section{Introdução}

Pouco se pesquisou e se vem pesquisando a literatura goesa ou indoportuguesa no Brasil, mas gradualmente ela vem despertando o interesse do meio acadêmico e seu estudo vem tomando corpo. Assim, os nomes, tanto de autores quanto de obras, são ainda bastante desconhecidos do público brasileiro. Vimala Devi, Gip e Agostinho Fernandes são alguns deles que podem soar familiares apenas aos pesquisadores, enquanto que, para o público leitor brasileiro em geral, continuam tão desconhecidos como sempre foram.

Sobre Alberto Osório de Castro, poeta e magistrado português, além de sua amizade com Camilo Pessanha, muito pouco se sabe. Apesar de nascido em Portugal, o autor viveu grande parte de sua vida nas colônias que seu país natal mantinha na Ásia, onde exerceu a função de juiz. Também teve passagem breve por Angola, na África, de onde pediu retransferência para a Ásia.

Foi objeto de estudo de duas teses de licenciatura em Filologia Românica, em 1959 e 1970. A primeira, redigida por Ana Maria da Conceição Oliveira, consiste em

um ensaio bio-bibliográfico e crítico e a segunda, redigida por Maria Celeste de Castro 
consiste em uma análise que pretende abordar Alberto Osório de Castro como homem e escritor, assim como sua obra. Desde então muito pouca ou mesmo nenhuma atenção esteve voltada a sua figura ou sua obra.

A presente dissertação, composta por três capítulos, tem como objetivo averiguar em que extensão a estada do autor no Oriente teve influência sobre sua obra poética, a partir da análise do diálogo que seus poemas estabelecem com os temas e as formas da tradição oriental, com especial atenção à indiana.

No primeiro capítulo tratamos de investigar e apresentar ao leitor quem foi Alberto Osório de Castro, homem, poeta e juiz. A abordagem se inicia pela infância do poeta, uma vez que parece ser dessa época que seu interesse, que duraria a vida toda, pelo Oriente se origina. Tendo passado muito tempo acamado por sua frágil condição de saúde, o menino Alberto Osório de Castro tem por companheiros livros e revistas que o levam a passear ao redor do mundo e a se iniciar seu caminho tanto na literatura quanto na sua relação com a Ásia.

No capítulo seguinte abordamos a questão da estética decadentista e simbolista na qual a obra poética de Osório de Castro está inserida. Aqui são revistas suas contribuições para o periódico Boémia Nova, nas quais o poeta critica o movimento literário imediatamente anterior, o Naturalismo, e defende os ideais decadentistas e simbolistas.

O terceiro capítulo, dividido em duas partes, visa investigar como é feita a abordagem e apropriação do Oriente na obra poética de Alberto Osório de Castro como mito e não como tema. A segunda parte é dedica à análise do poema "Sati", provavelmente sua produção na qual a influência do Oriente é mais perceptível.

As considerações finais pretendem fazer um apanhado geral e mostrar ao leitor de que forma a apropriação que Osório de Castro faz do Oriente em sua obra poética dialoga com aquela realidade até que ponto é original. 


\section{Capítulo 1}

\section{Acerca do autor, seu tempo e sua obra}

Magistrado português que exerceu o ofício principalmente nas colônias, poeta e escritor, Alberto Osório de Castro é mais conhecido por sua grande amizade com o poeta Camilo Pessanha do que por sua própria obra. Nascido a primeiro de Março de 1868, filho do Dr. João Baptista de Castro e de D. Marianna de Castro Cabral e Albuquerque Moore Hincio, tem três irmãos: Ana, João e Jerônimo. Apesar de ter nascido em Coimbra, só volta a residir na cidade natal durante os anos em que cursa a Faculdade. Sua infância é passada em companhia dos pais em Magualde. Em janeiro de 1878, contando então dez anos é matriculado na Escola Acadêmica de Lisboa e fica morando na casa de sua tia, Maria Cândida Fonseca Mangas. Durante esse período só retorna à casa dos pais nos meses de férias. 
Nota-se o gosto pela escrita desde cedo, quando, aos onze anos, começa a registrar minuciosamente suas experiências em um pequeno diário que chama de "A minha vida". A partir de seus textos poéticos é possível conhecer um pouco sobre a infância de Osório de Castro, período de sua vida sobre o qual não se encontra muita informação disponível. Todavia, é importante ressaltar que poesia não é biografia e que, portanto, as referências encontradas podem ter sido alteradas e romanceadas pelo autor.

Em "Febre D'exílio", o primeiro poema de Exiladas, seu primeiro livro, encontramos referência a Portugal e a sua infância:

Fui enfermiço e tive uma pálida infância.

Doce, faltou-me sempre a viril arrogância

Fraco, com uma pobre infância muito breve,

Sempre doente, a fazer castelos infinitos ${ }^{1}$

$\mathrm{Na}$ obra Cristais de Neve, que só vem a público na edição de suas obras completas em 2004, num poema intitulado "Ténue lumieira nas sombras e na distância", o poeta fala não apenas sobre sua infância mas também sobre os personagens que dela fizeram parte.

A minha mãe fiava muito bem na sua roca

No inverno, com serões, minha Mãe então fazia

Nos baús antigos seu bragal ir a crescer.

M, para descansar, seus amados livros lia.

Descanso de meu Pai, era, às noites também ler.

Aos quatro anos eu sabia ler por cima

1 CASTRO, A. O. Exiladas. In: Obra Poética. Vol. I. Lisboa: Imprensa Nacional Casa da Moeda, 1994. v.1. p. 53. 
Pouco se dava em casa de saber vidas alheias

E às da gente só dos livros atenção se lhes prestava.

Lá íamos à deita, as cabeças todas cheias

De contos. Nossa Mãe muito bem que os contava.

Falava-nos da Mãe, que era estrangeira e era suave.

Do Pai, que bravamente china piratas perseguira,

Vêm-me da Avó talvez as saudades que sentira,

Deste Avô o fervor do seu sonho firme e grave..."

Como cheiravam bem os charutos do padrinho!

Os do bom Dr. Almeida, em sua capa à espanhola,

Traziam a saúde ao pobre doente miudinho

Que no sonho ia perdendo experiências só de Escola. ${ }^{2}$

As descrições que Osório de Castro faz são poetizadas, ficcionalizadas e não o que de fato aconteceu necessariamente, até certo ponto é possível dizer que ele tenha inventado o próprio passado; mas elas expõem ao leitor o tipo de ambiente em que o menino Alberto cresceu: uma casa na qual o conhecimento adquirido através da leitura e a experiência de vida que se adquire através e durante viagens eram de grande importância. Esses são valores que o acompanharão pelo resto da vida e que pesarão e influenciarão em suas decisões profissionais, levando-o à Ásia e à África como magistrado e, posteriormente, a integrar delegações na Europa.

O diário do poeta, na verdade apenas quatro pequenas folhas, escrito em 1879 em que registra suas primeiras memórias, também serve de guia para melhor se conhecer e entender quem foi aquela criança, que se levava muito a sério.

Um rapazinho de onze anos chama pomposamente a estas referências $A$ minha Vida. Forçada inactividade de convalescente, imitação de hábitos que via

2 CASTRO, A. O. Últimos Poemas. In: Moeda, 2004, v.2. p. 409.

Obra Poética. Lisboa: Imprensa Nacional Casa da 
à sua volta, o certo é que as linhas traçadas pela sua mão infantil nos ajudam a entrever uma figurinha com gosto de escritor, zeloso das suas notas, introspectivo até à minúcia. ${ }^{3}$

A figura que se pode traçar a partir destas informações coletadas é a de uma criança de compleição frágil e aspecto franzino, que continua acreditando ingenuamente no que ele mesmo diz e por isso é importante manter distanciamento crítico desse personagem que ele desenha para si mesmo, afim de poder separar o autor do homem. Por causa de sua saúde frágil, teria passado bastante tempo acamado, sempre a recuperar-se de alguma doença oportunista.

[...] e já bastante doente, e fui logo deitar-me com uma entrite aguda, que me fez estar em prigo de vida bastantes vezes; hoje 30 de Março de 1879 em que escrevo estes apontamentos ainda me conservo na cama com uma bronchite, restos da encomenda. ${ }^{4}$

Por causa do muito tempo que passou recluso e também por imitação dos hábitos que via à sua volta, adquiriu uma cultura excepcional através da leitura dos livros da biblioteca paterna e também de alguns periódicos literários, científicos e de ilustração franceses, como Tour du Monde, L'Univers Pittoresque e Revue Rose.

Em setembro de 1878 vai a Felgueira tomar banhos com alguns familiares e dessa viagem volta bastante doente, com uma enterite que o fez estar em grande perigo de vida e que quase um ano depois ainda o assombrava na forma de bronquite. O menino Alberto Osório de Castro, por sua frágil condição de saúde, não retorna a Lisboa e permanece na casa de seus pais. Passa então a receber, em casa, lições de uma jovem preceptora. Era ela D. Catharina de Sousa Coutinho, uma moça de Mangualde

\footnotetext{
${ }^{3}$ BERNARDO, M. C. S. Alberto Osório de Castro - o homem, o escritor, a obra. Tese (Licenciatura em Filologia Românica). Faculdade de Letras, Universidade de Lisboa, Lisboa, 1971, p. 8.

${ }^{4}$ Excerto do diário do poeta. In: BERNARDO, M. C. S. Alberto Osório de Castro - o homem, o escritor, a obra. Tese (Licenciatura em Filologia Românica). Faculdade de Letras, Univeridade de Lisboa. Lisboa, 1971, p. 7.
} 
que contava com dezessete anos na época: "O seu espírito fantasioso tece então já românticos amores por essa sua professora, com quem veio a se casar."5 Mais tarde, em 1906, quando já havia sido transferido para Goa, escreve o poema "Interiora (Agosto 11, 1883)" que traz claras referências ao início de seu romance com sua preceptora.

Já tinha quinze anos, e tu eras

Mais velhinha do que eu.

E a flor de amor das nossas primaveras

Nesse dia nasceu.

Nesse dia? Não, certo. Amo-te, creio

Desde o primeiro dia

Em que te vi, desde o primeiro anseio

De amor e de poesia.

Mas nesse dia fomo-nos sentar

No banco da parreira.

Vinha uma tarde esplêndida dourar

As sombras da carreira.

E eu, que te tratava como irmão,

Perguntei-te: Quer ter

Para sempre a minha alma na sua mão?

Quer ser minha mulher?

E tu foste adorável, no esplendor

De esse divino agosto.

Aceitaste da criança o puro amor,

${ }^{5}$ BERNARDO, M. C. S. Alberto Osório de Castro - o homem, o escritor, a obra. Tese (Licenciatura em Filologia Românica). Faculdade de Letras, Universidade de Lisboa, Lisboa, 1971, p. 10. 
Beijaste-a no rosto.

E é sempre nova que te vejo, como

No banco da parreira,

Nesse agosto cheiroso como um pomo,

Dourado como a eira.

Envelheceres, tu? És com como o amor

Com que sempre te amei.

E nova hei-de te ver na extrema dor

Que em vida sentirei ${ }^{6}$

Alberto e Catharina tiveram, ao que tudo indica, doze filhos, dos quais apenas quatro vingaram e cuja maior parte nasceu no Oriente.

Durante seus anos de estudo faz contribuições aos jornais Boémia Nova - Revista de Litteratura e Sciencia e O Novo Tempo, Jornal da Esquerda Dynastica, do qual é o redator. Boémia Nova é escrita sob a direção do Dr. Fausto (pseudônimo de Alberto Osório de Castro, Alberto Oliveira e Antonio Nobre) e surge em fevereiro de 1889, com o intuito de preencher uma lacuna, em vista da falta de um jornal acadêmico em Coimbra. Seus autores pretendem reavivar a boemia literária com a publicação do periódico.

Em Coimbra não há propriamente vida litteraria, embora haja uns restos de vida academica, que as qualidades excepcionaes da terra hão-de constantemente manter.

[...] Hoje, em Coimbra, não há bohemia litteraria, nem cenaculo, nem jornal, nem coisa nenhuma; há, pura e simplesmente, rapazes que escrevem e que publicam os seus escriptos nos diversos jornaes do paiz. N'estes ultimos annos, uma revista litteraria que aqui appareça, não dura mais de tres mezes: - e

${ }^{6}$ CASTRO, A. O. A Cinza dos Mirtos. In: . Obra Poética. - Lisboa: Imprensa Nacional Casa da Moeda, 2004, v. 1. p. 189-191. 
já é um caso raro.

[...] É um jornal de rapazes de hoje a Boémia Nova; procurará ser tambem um jornal de ideias modernas, de orientação moderna, de modernissima eschola. ${ }^{7}$

Boémia Nova tem uma relação de rivalidade com a publicação de Eugénio de Castro Os Insubmissos. Há entre ambos os periódicos uma mútua acusação de plágio, especialmente no que diz respeito à questão da cesura do verso alexandrino, da qual se ocupa extensamente Eugénio de Castro no prefácio do seu livro Oaristos. Apesar de todo empenho de seus colaboradores, a revista, que teve seu início em fevereiro de 1889, chega a seu fim em abril do mesmo ano. É curioso notar que a publicação envereda pelo mesmo caminho de suas antecessoras, durando apenas três meses, fato que fora muito criticado no artigo inaugural.

Enquanto que em Boémia Nova o autor trata de temas ligados ao campo da literatura, mostrando um desejo de ruptura com os métodos antigos e uma visão mais moderna, já aderindo aos novos movimentos literários como o Decadentismo e o Simbolismo, n'O Novo Tempo mostra seu lado mais conservador, ao escrever para um jornal vinculado à esquerda dinástica, facção mais à esquerda do Partido Regenerador, e tratar de assuntos de interesse da população de Mangualde em geral. Os poemas publicados em O Novo Tempo foram depois publicados nos livros Exiladas e A Cinza dos Myrtos.

Em 1890, Alberto Osório de Castro forma-se bacharel em Direito pela Universidade de Coimbra e começa sua carreira como juiz municipal em Óbidos. Pouco tempo depois pede para seguir para o Oriente, muito provavelmente por causa de umas saudades que de lá sentia e que foram herdadas de sua avó materna. "Das saudades dela fiz saudades minhas..." ${ }^{8}$ É um tanto romântico imaginar que essa seja a única razão que faz Osório de Castro se decidir por uma transferência e pedi-la. Somase a isso a crise financeira pela qual passou o Estado português no final do século XIX,

\footnotetext{
7 https://bdigital.sib.uc.pt/bg4/UCBG-OS-1024/UCBG-OS-1024 item1/P5.html Consultado em 14/05/2012

${ }^{8}$ CASTRO, A. O. A ilha verde e vermelha de Timor. Lisboa: Edições Cotovia, 1996, p. 17. 
o que reduzia as chances de boas colocações na metrópole: "Por fim, contrariamente ao antigo, o novo imperialismo incentivou a transferência do excesso de população das metrópoles para as colônias." ${ }^{\prime 9}$ Com isso vem um provável incentivo da Coroa para o deslocamento de funcionários do governo para as colônias. "Mas a família cresciaIhe, e, por necessidade com certeza, e certo gosto que o espírito curioso e sonhador impunha, pedir para seguir para o Oriente."10

Como bem pontua Álvaro Manuel Machado, em seu $O$ mito do Oriente na literatura portuguesa ${ }^{11}$ o homem português tem a paixão pela descoberta, pelo novo e vai ao Oriente não apenas por razões politico-econômicas, mas também por curiosade pelo exótico, que seria um produto das heranças clássica e cristã. É provavelmente também daí que vem a curiosidade e a necessidade que Osório de Castro sente de ir para o Oriente.

É então nomeado delegado da comarca de Salcete e em 1894 parte para a Índia, onde permanece por treze anos. Durante esse período passa uma curta temporada de férias em Portugal. Da Índia segue para Angola, onde fica pouco tempo, apenas durante o ano de 1907, como juiz da comarca de Moçâmedes, e de lá pede transferência para o Timor.

A estada na África em nada agradou Alberto Osório.

E na infinita desolação da costa atlântica a África austral, amortalhada rogo a meio do dia em taciturno cacimbo, eu só sonhava em tornar à resplandecente magia dos países do Oriente, ou, melhor ainda, do Extremo-Oriente. VInhamme à lembrança gravuras admiradas na minha infância, ilustrando em Le Tour du Monde a tradução francesa da obra do grande naturalista inglês Alfred Russell

\footnotetext{
${ }^{9}$ MELLO, L. I. A. e COSTA, L. C. A. História Moderna e Contemporânea. São Paulo: Scipione, 1999. p. 269.

10 BERNARDO, M. C. S. Alberto Osório de Castro, o homem, o escritor, a obra. Tese (Licenciatura em Filologia Românica) Faculdade de Letras, Universidade de Lisboa. Lisboa, 1971. p. 11

11 MACHADO, A. M. $\mathbf{O}$ mito do Oriente na literatura portuguesa. Lisboa: Instituto de Cultura e Língua Portuguesa, 1983.
} 
Wallace, The Malay Archipelago. ${ }^{12}$

$[\ldots]$

Pedi transferência para Timor, e houve a bondade no então Ministério do Ultramar de se atender a minha súplica, creio até que principalmente pelo argumento evocado do preço do caixão de ir à cova no cemiteriozinho de Moçâmedes, rondado à noite pelas hienas ou quimalancas do escuro deserto circundante. Fui, porventura, creio, o primeiro juiz colonial que requereu colocação em Timor...13

Como juiz da comarca de Moçâmedes pede transferência para Timor, onde permanece entre os anos de 1908 e 1911. Há uma tradição familiar, iniciada pela avó materna de origem holandesa nascida na Batávia, depois continuada pelo avô materno que foi juiz em Macau, que liga o poeta ao Oriente. Já desde menino se sente atraído por aquela parte do mundo, muito por conta das iguarias que lhe preparava a avó, como o aluá, a bebinca, os bítchu-bítchu, que futuramente aparecem em sua obra poética:

Pois minha pobre avó, exilada do Extremo-Oriente da sua meninice à sua mocidade, lá foi morrer na Muxagata, na aspereza da Alta Beira, serrania da Estrela ao longe.

$[\ldots]$

As saudades que esses nomes [dos doces acima citados] não dariam à pobre exilada, nostálgica e transida naquele casarão de aldeira da Alta Beira. ${ }^{14}$

Por estas razões familiares, o Timor é a colônia que, provavelmente, mais sensibiliza o poeta e a única sobre a qual ele se dedica a escrever um tratado a respeito da terra e não aparece apenas como citações em seus poemas.

12 CASTRO, A. O. A ilha verde e vermelha de Timor. Lisboa: Edições Cotovia, 1996. p. 16

13 Idem, p. 14

14 Idem, p. 16 
Em outubro de 1911 retorna a Angola onde é colocado como Desembargador da Relação de Luanda, seu último posto fora de Portugal. De Luanda regressa a Lisboa, onde assume o cargo de Juiz Conselheiro do Supremo Tribunal de Justiça, posto onde se aposentou. Em 1918, enquanto Secretário de Estado de Justiça do governo de Sidônio Paes, vai para a cidade francesa de Ambleteuse, como Juiz Auditor do Corpo Expedicionário Português em França, lá ficando até a primavera de 1919.

Após essa estada na França, retorna a Portugal para exercer a função de Presidente do Conselho Superior de Administração Pública e Vice-Presidente de Conselho do Império. Quando, em 1946, vem a falecer, já estava aposentado como Juiz Conselheiro do Supremo Tribunal de Justiça em Lisboa.

Apesar de sentir-se atraído pelo Oriente e lá ter vivido por cerca de dezessete anos, é sempre com uma visão de ocidental, como ele mesmo reconhece, que faz suas observações: "As pinturas chinesas do Museu de Camilo são um pouco, aos meus olhos de Ocidental, como esta poesia singular, que em mim evoca um infindo abismo, de translúcido vácuo. Também isto tem seu encanto". ${ }^{15}$

O tema é recorrente em sua obra desde antes de se lançar na empreitada ultramarina e se torna presença constante depois de voltar definitivamente a Portugal. Já em Exiladas, seu primeiro volume de poesias reunidas, publicado em Coimbra em 1895, são encontradas referências ao Oriente. No poema "Crisântemas", fala sobre o monte japonês Fúsi-no-Yama. O próprio título da coletânea, "Exiladas", pode ser interpretado como uma referência à herança familiar (avó que foi exilada em Portugal) e ao próprio poeta que, na condição de magistrado, vai para o Oriente.

Em vista do desconhecimento atual de sua obra, convém fazer um apanhado geral dos livros do poeta, assim como das datas e locais de suas publicações. Como dito logo acima, seu primeiro volume de poesias leva o título "Exiladas" e foi publicado em Coimbra no ano de 1895 pela Livraria França Amado, quando o poeta

15 CASTRO, A. O. Camilo Pessanha em Macau. In: LANCASTRE, M. J. Camilo Pessanha, cartas a Alberto Osório de Castro, João Baptista de Castro e Ana de Castro Osório. - Lisboa: Imprensa Nacional Casa da Moeda, 1984. 
já ocupava seu cargo de magistrado na Índia. É composto, em grande parte, por poemas que haviam, inicialmente, sido publicados em $O$ novo tempo, o jornal da esquerda dynastica. É um livro com caráter essencialmente autobiográfico, cujos poemas escritos já no Oriente ainda se encontram impregnados das recordações de Portugal: "É sobretudo de Portugal que o livro trata e da juventude do poeta passada em Mangualde e em Coimbra". 16

Seu segundo volume de poesias reunidas, A Cinza dos Myrtos foi publicado em 1906, na Índia, pela Imprensa Nacional de Nova-Goa, e é dedicado à Senhora Condessa Mathieu de Noailles. Assim como Exiladas, este livro também é, em parte, composto por poemas que haviam previamente sido publicados no jornal $O$ novo tempo. A maioria deles, no entanto, é escrita a caminho do Oriente ou já em Goa. Praticamente todos os poemas encontrados em A Cinza dos Myrtos são dedicados a alguém, familiares ou amigos.

O terceiro volume, Flores de Coral, constituído por "Poemetos e Impressões da Oceania Portuguesa", segundo palavras do próprio autor, é o primeiro livro a ser publicado pela Imprensa Nacional de Díli na llha de Timor, em 1908. É dedicado a Fialho de Almeida. São impressos 72 exemplares em papel Song-Kio-Tzo de Cantão, assinados e rubricados pelo autor, 257 são impressos em papel TCO-TPO - papel pagode de Cantão - e 31 exemplares, também rubricados e numerados, são impressos nos dois papéis mesclados.

O quarto volume, intitulado O Sinal da Sombra, é publicado em Lisboa, pela Livraria Clássica Editora de A. M. Teixeira e Companhia, em 1923. Assim como nas outras obras, os temas do amor, da morte, do tempo, do fluir da vida e das saudades são retomados.

No ano de 2004 a Imprensa Nacional Casa da Moeda reuniu em dois volumes sua obra completa na série Biblioteca de Autores Portugueses. No segundo volume se encontra publicado pela primeira vez o até então inédito Cristais de Neve, que reúne

16 OLIVEIRA, A. M. C. Alberto Osório de Castro, ensaio bio-bibliográfico e crítico. Tese (Licenciatura em Filologia Românica) Faculdade de Letras, Universidade de Lisboa. Lisboa, 1959. p. 38. 
poesias escritas nas diferentes épocas de sua vida. Este é dedicado à sua mulher, dona Catharina, ao lado de quem passou toda sua vida. Ao final do segundo volume há uma coletânea intitulada Últimos Poemas, que reúne a produção dos anos de 1942 a 1945.

Seu único livro em prosa, $A$ ilha verde e vermelha de Timor, teve sua primeira edição quando o autor ainda era vivo, em 1943. É um tratado sobre a ilha de Timor, no qual o autor discorre sobre a fauna, a flora, costumes e língua locais.

Suas contribuições tanto à revista literária Boémia Nova, quanto ao jornal $O$ Novo Tempo não foram compiladas, mas podem ser consultadas pela internet ou em microfilme na Biblioteca Nacional de Portugal. Afim de melhor entender o escritor e poeta, é essencial consultá-las para dele ter uma melhor compreensão de quem foi este homem, uma vez que são nestas obras que expõe suas idéias acerca do movimento literário no qual está inserido e a época em que vive.

Em Alberto Osório de Castro; o homem, o escritor, a obra, dissertação de Maria Celeste da Silva Bernardo, é encontrada uma lista de trabalhos do autor que não saiu do plano de preparação. Entre essas obras inéditas há um livro de versos chamado A Mesquita D'Oiro, alguns romances intitulados Alma D'Oriente e Água de Bangania, que tratariam sobre a vida européia em Goa, dois volumes dramáticos Dom Sebastião e Auto da Alma, um volume que conteria as poesias indianas de Luis de Camões, comentadas por Osório de Castro e, por fim, um volume intitulado Plantas úteis de Timor, que complementaria $A$ ilha verde e vermelha de Timor. 


\section{CAPÍTULO 2}

\section{A questão estética}

Tendo traçado um breve perfil do homem e do poeta Alberto Osório de Castro, assim como feito um breve levantamento de sua obra, vejamos em que cenário histórico, estético e cultural sua produção se deu, para melhor compreendê-la.

Antes do início do movimento artístico literário que foi chamado de Decadentismo, já se falava no sentimento de Decadência, que tinha uma inclinação pessimista no que diz respeito à evolução da história coetânea. Acompanhando este sentimento vem uma identificação com épocas históricas estigmatizadas pela decadência como Bizâncio e Roma e com isto a "valorização das formas artísticas geradas, de modo específico, como adequada tradução daquele modo de sentir a vida"17

Segundo Seabra Pereira, em Decadentismo e simbolismo na poesia portuguesa, a linha de passagem entre o sentimento de Decadência e o movimento

17 PEREIRA, J. C. S. Decadentismo e simbolismo na poesia portuguesa. Coimbra: Centro de estudos românicos. 1975, p.18 
artístico literário Decadentismo é traçada no momento em que os estetas passam a denunciar a corrupção da sociedade da época e tem como grande marco o poeta francês Charles Baudelaire. Para ele, a arte, por motivos de refinamento superior, já se distingue da decadência que a rodeia.

"O que parece caracterizar primariamente o Decadentismo é um estado de sensibilidade."18 Há um sentimento de revolta contra os padrões da sociedade burguesa, os poetas estão fartos do tecnocratismo e do convencionalismo moral dessa classe. Junto a isso, "agudiza-se a consciência de um estado de decadência social e cultural". 19 O movimento afirma-se, então, ao tomar a forma do mal du siècle, como uma luta pela libertação dos padrões rígidos e convenções vitorianas que haviam tomado conta da vida e da arte.

Quem inaugura o movimento é Théophile Gautier, ao compor o prefácio para a edição definitiva de Les Fleurs du Mal, em 1868, a primeira edição póstuma do livro, que seria consagrado como o "primeiro manifesto da poesia e temas decadentistas". 20 No entanto, é apenas por volta de 1880 que o termo decadence e os que dele derivam passam a ser utilizados para designar uma nova temática predominante, uma nova forma de arte, após a publicação do texto de Anatole Baju no Le Décadent litteraire et artistique, em abril de 1886. O manifesto "Aos Leitores!" é aberto com a constatação do estado de decadência a que chegara a Europa e com a constatação de que negá-lo seria impossível: "o homem moderno é um insensível", pondera o autor, após enumerar uma série de aspectos da sociedade que se encontram em franca decadência, tais como afinamento de apetites, de sensações, nevrose, histeria, charlatanismo científico e schoppenhauerismo em excesso. Anatole Baju, depois de elencar o que há de errado com a situação atual e apontar um a um os problemas, diz que se ocupará doravante apenas da arte, pois "a arte não tem partido; é o único ponto de reunião de todas as

\footnotetext{
18 Idem, p. 22

19 Idem, p. 23

20 TELLES, G. M. (Org). Vanguarda Europeia e Modernismo Brasileiro. Petrópolis: Editora Vozes, 1997. p. 55.
} 
opiniões $^{21 ",}$ e termina por afirmar que

Nós seremos as vedetes de uma literatura ideal, os precursores do transformismo latente que desgasta as camadas superpostas do clacissismo, do romantismo e do naturalismo; em uma palavra, nós seremos os enviados de Alá clamando eternamente o dogma elixirizado, o verbo demasiado sutil do decadentismo triunfante. ${ }^{22}$

Junto ao Decadentismo surge um sentimento religioso que, apesar da inclinação neocatólica, não adere a qualquer tipo de ortodoxia, pois deseja se fundir com o ocultismo: "Coerente consigo mesmo, e sugestionado por idênticas inclinações de movimentos precursores, o Decadentismo apaixona-se pelas ciências ocultas e aspira à exploração de vias esotéricas de comunicação com o Além."23 Esta inclinação tem a ver com a reação contra o Naturalismo, na medida em que, ao se voltar para a religião, nega "o mundo ou a natureza como regula vitae". ${ }^{24}$

Causa ou efeito das aspirações e das limitações atrás referidas, e sentimento exacerbado por cada insucesso, o individualismo afirma-se como marca indelével do escritor decadista. E, porque decidido egotista, ele tem de auscultar amorosa e languidamente o seu próprio mistério interior. ${ }^{25}$

Isso faz com que a poesia decadista desprenda-se de uma perspectiva objetivante e que use a realidade interior como estímulo emocional para refletir impressões sentidas. Desse modo, a rêverie, o estado de indefinido devaneio interior geralmente ritmado por uma musicalidade, tem grande influência na escrita poética decadista. Mas nem tudo é

\footnotetext{
${ }^{21}$ BAJU, A. Aos Leitores! In: MENDONÇA, G. T. (Org.) Vanguarda Europeia e Modernismo Brasileiro. Petrópolis: Editora Vozes, 1997. p. 57-8.

22 Idem, ibidem.

23 PEREIRA, J. C. S. Decadentismo e simbolismo na poesia portuguesa. Coimbra: Centro de estudos românicos. 1975. p. 32-33

24 Idem, p. 31

25 Idem, p. 33 
rêverie e o que se contrapõe às imagens da luz outonal, perfumes e sensações oníricas prazerosas é o conturbado mundo interior, marcado especialmente pela nevropatia.

"Feridos por tudo o que os contorna, vivem da sua rejeição, mas perdem, na tensão da luta, o equilíbrio psíquico e nervoso. É a época de Les Névroses"26. São estas névroses que levam os decadistas a buscar, nos passos de Baudelaire, os paraísos artificiais e com ele vão descobrindo o exótico, os "caminhos que levam à fruição das sensações requintadas." 27

A figura feminina não fica de fora do Decadentismo mas, ao contrário da mulher fatal romântica, a mulher decadente é nevrótica e tem um caráter sobrenatural, que faz com que exerça um domínio irresistível, mas cujo desejo é irrealizável. É impossível falar da figura feminina sem tocar na temática do amor, que nesse movimento artístico-literário tem mais acentuada, na obra de certos autores, seu caráter "laico do ascetismo cristão", em contraponto ao Romantismo. Já dando mostras do Simbolismo, que está à espreita, são constantes os tópicos como perfumes, cores imponentes, metais e pedras preciosas: "O poema de amor pretende tomar a forma de salmo, mas dentro da ambígua conjunção de tais elementos." 28

A recusa total do culto romântico da Natureza, o desafecto pelo idealismo amoroso, a estreita fusão de sensibilidade e raciocinação, o afastamento constante do emocionalismo exaltado, o alheamento de postura ou linguagem heróicas, tornam as posições do Decadentismo diferentes das que, a propósito de temas e situações por vezes muito próximos, tomara o Romantismo. ${ }^{29}$

Tanto a criação poética quanto o alcance da lírica, não foram objetos de teorização literária sistemática, como diz Seabra Pereira. Há, contudo, um sentimento com base

\footnotetext{
${ }^{26}$ Idem, p. 35

27 Idem, ibidem

28 Idem, p. 39

${ }^{29}$ Idem, p.45-6 
científica de que a singularidade do gênio e a insanidade mental estariam ligados. "A meio caminho entre a assunção teórica e a adesão implícita está, no Decadentismo, o alinhamento pelos princípios da arte pela arte."30

Há o desejo do distanciamento de movimentos anteriores, como o Parnasianismo, o Romantismo e o Realismo, apesar de haver no Parnasianismo um culto à beleza e uma preocupação quanto ao rigor da forma que exercem forte influência no movimento Decadentista e, posteriormente, no Simbolista.

Por causa de sua própria natureza, que se baseia nas condições políticas e culturais da época em que se insere, o movimento Decadentista não tarda a findar e é absorvido pelo Simbolismo em pouco tempo, movimento que inicialmente se confunde com o Decadentismo.

O Simbolismo nasce em fins do século XIX em Paris e não na França, como faz questão de salientar Ana Balakian em seu O Simbolismo. A autora dá bastante importância para o fato de que o movimento é considerado parisiense por seu aspecto cosmopolita, abrindo as portas para o clima internacional que vem a ser de grande importância para os próximos grupos de vanguarda. "Com o simbolismo, a arte deixou realmente de ser nacional e assumiu as premissas da cultura ocidental." 31

O movimento surge em reação ao Realismo e ao Naturalismo, que eram consideradas correntes analíticas, por causa de sua intenção de descrever o mundo a partir de uma ótica o mais próxima possível da realidade e o mais desvinculada possível de uma visão idealizada, como fora o caso do Romantismo, escola literária que tinha como principal característica a idealização. O Simbolismo vai contra às "soluções racionalistas e mecânicas e nestas reconhecem o correlato da burguesia industrial em ascenção"32. Sua proposta é "ir além do empírico e tocar, com a sonda da poesia, um fundo comum que susteria os fenômenos, chame-se Natureza, Absoluto,

\footnotetext{
30 PEREIRA, J. C. S. Decadentismo e simbolismo na poesia portuguesa. Coimbra: Centro de estudos românicos. 1975. p. 49

31 BALAKIAN, A. O Simbolismo. São Paulo: Perspectiva, 2007. p. 15

32 BOSI, A. História concisa da literatura brasileira. São Paulo: Cultrix, 2003, p. 263 
Deus ou Nada."33

O movimento tem inspiração em poetas como Baudelaire, em autores como Dostoiévski e um veio antiburguês, na medida em que se opõe ao racionalismo calculista e capitalista. Sua proposta é uma "apreensão direta dos valores sentimentais, o Bem, o Belo, o Verdadeiro, o Sagrado"34, sempre a partir de uma visão bastante pessoal e individualista da realidade.

Em significativa parte dos escritores do Simbolismo, encontramos uma configuração platónica da visão do Mundo: sobreposição de duas realidades distintas, sendo uma - a material, fenoménica, sensivelmente atingível - destituída de valor em si, porque considerada apenas como anúncio simbólico da outra - a realidade espiritual, imperecível e plena. ${ }^{35}$

O sonho, na medida em que aproxima o indivíduo de si próprio, também é de fundamental importância para os poetas simbolistas. O romântico busca o sonho desde a terra, como um substituto para o céu que almeja, enquanto que "[...] o simbolista cultivava os sonhos como o único nível vital da experiência do poeta [...]"36.

Escrito por Jean Moréas, o Manifesto Simbolista é publicado pela primeira vez no Le Figaro em 1886. Inicia com a reflexão da evolução cíclica da arte, como a passagem do tempo revoluciona tudo e cada nova fase simplesmente invalida a que imediatamente terminou. Ademais, há também uma ponderação acerca do esgotamento que invariavelmente acomete toda manifestação artística: o que uma vez foi apresentado como novo, após inúmeras cópias e imitações, perde o viço. Portanto, uma nova manifestação de arte, para suceder o Romantismo, era necessária e inevitável. Dadas as características que a identificam, como o abuso da pompa e o vocabulário novo, maior e mais elaborado, é proposta a denominação de "Simbolismo

\footnotetext{
33 Idem, p. 263

34 BAJU, A. Manifesto Simbolista. In: TELES, G.M. (Org.). Vanguardas Europeias e Modernismo Brasileiro - Petrópolis: Editora Vozes, 1997. p.57

35 PEREIRA, J. C. S. Decadentismo e simbolismo na poesia portuguesa. Coimbra: Centro de estudos românicos 1975. p. 66

36 BALAKIAN, A. O Simbolismo. São Paulo: Perspectiva, 2007. p. 20 
como a única capaz de designar razoavelmente a tendência atual do espírito criador em arte." 37

Segundo Moréas, a poesia simbolista é inimiga do ensino, da declamação, da falsa sensibilidade e da descrição objetiva; ela busca "vestir a Idéia de uma forma sensível que, entretanto, não terá seu fim em si mesma, mas que, servindo para exprimir a Idéia, dela se tornaria submissa."38 Além da questão das Idéias, evidenciada pelo vocabulário amplo e novo, a boa língua, como diz Moréas, e as construções complexas, há o ritmo.

O RITMO: a antiga métrica avivada; uma desordem sabiamente ordenada; a rima brilhante e martelada como um escudo de ouro e de bronze, perto da rima as fluidezas absconsas; o alexandrino em paradas múltiplas e móveis; o emprego de certos números ímpares. ${ }^{39}$

Há neste movimento literário uma tentativa de aproximação da poesia à música e para isso lançam mão de recursos como aliteração, a repetição de uma mesma consoante, e assonância, a repetição de uma mesma vogal, quebrando então com a forma rígida do Naturalismo, que fazia largo uso do verso alexandrino.

Quem primeiro se ocupa dessa questão dos versos alexandrinos no âmbito da literatura portuguesa é Eugénio de Castro no prefácio de Oaristos (1890) ao qual dá início pontuando o atual estado da poesia portuguesa contemporânea, que "assenta sobre algumas dezenas de coçados e esmaiados lugares comuns". ${ }^{40} \mathrm{~A}$ preocupação inicial de Eugénio de Castro parece recair sobre a linguagem utlizada pelos poetas que teimam em comparar olhos a estrelas, dentes a fios de pérolas, bem como mulheres a tímidas gazelas.

\footnotetext{
${ }^{37}$ MORÉAS, J. Manifesto Simbolista. In: TELLES, G.M. (org.) Vanguarda européia e modernismo brasileiro Petrópolis: Editora Vozes, 1997, p. 63.

38 Idem, p. 63

39 Idem, p. 64

${ }^{40}$ CASTRO, E. Oaristos In. VOUGA, V. (org.). Obras poéticas de Eugênio de Castro - Porto: Campo das Letras, 2001. p. 55. 
No tocante a rimas, uma pobreza franciscana [...] No tocante a vocabulário, uma não menos franciscana pobreza: talvez dois terços das palavras, que formam a língua portuguesa, jazem absconsos, desconhecidos, inertes, ao longo dos dicionários, como tarecos sem valor em lojas de arrumação. ${ }^{41}$

O autor então compara o atual estado da poesia portuguesa a uma viagem de trem, que pode ser lenta ou rápida e cujos destinos são muitos: há a garre da posteridade, a garre da originalidade e a "concorridíssima estação da VULGARIDADE"42. Deixa-nos, então, conhecer que após alguns anos viajando no trem lento com destino à estação da vulgaridade, agora decidiu mudar de comboio e direção, deixando todo o passado para trás, sem dele levar qualquer coisa em sua nova jornada.

Os Oaristos são as primícias dessa nova maneira do Poeta. Registrando: Êste livro é o primeiro que em Portugal aparece defendendo a liberdade do Ritmo contra os dogmáticos e estultos decretos dos velhos prosodistas. As ARTES POÉTICAS ensinam a fazer o alexandrino com cesura imutável na sexta sílaba. Desprezando a regra o Poeta exibe alexandrinos de cesura deslocada e alguns sem cesura. ${ }^{43}$

Além destas há outras inovações que aparecem em Oaristos, tais como a aliteração e as rimas raras. Dentre todas as novidades, a que parece se configurar como mais importante é a do vocabulário, mais extenso e rico em comparação ao limitado vocabulário corrente da atual literatura. O uso de palavras raras e pouco conhecidas é justificado pelo fato de que, como disse Baudelaire, elas têm, além da ideia que representam, uma beleza própria e, principalmente, "porque às fastidiosas

\footnotetext{
41 Idem, p. 56 - 7.

42 Idem, p. 57

43 Idem, p. 58-9 
perífrases prefere o têrmo preciso."44

Um movimento literário intitulado Simbolismo poderia ter poucas preocupações centrais além da questão do símbolo e do uso da linguagem. Como bem pontuou Eugénio de Castro em seu Oaristos e Jean Moréas em seu O Simbolismo, um uso mais amplo de vocabulário mais complexo e variado é uma das principais bandeiras do movimento. Contudo, a questão do símbolo no Simbolismo é mais complexa - diz respeito à capacidade da linguagem fundar a realidade em si e não simplesmente representá-la, como trata da questão Fernando Guimarães em Simbolismo, Modernismo e Vanguardas. Nele o autor aborda a questão do que considera ser um desinteresse pelo estudo dos períodos decandetista e simbolista, que seriam derivados de uma desconfiança do publico geral em relação ao que consideraria o bom gosto dos poetas e também de uma acusão que fariam sobre serem os decadentistas e simbolistas apenas formalistas, defensores da arte pela arte em oposição à poesia de intervenção ou empenhamento, que tem seu apogeu entre Junqueiro e o NeoRealismo, típico dos anos 40.

De todos os traços anteriormente apontados talvez fosse de dar um certo relevo àquele que corresponde a uma discreta, mas, apesar de tudo, efectiva preocupação quanto às transferências que na criação poética se estabeleceram entre um plano intelectual, que iria desde a fase significativa dos versos até aos "infinitos estados intelectuais comprimidos dentro de cada palavra" 45 , a um plano sensorial, que por sua vez, iria desse a "hiperstesia dolorosamente extrema dos [...] sentidos"46 ou das "vibrações estranhas do sensacionismo"47 - que curioso destino o desta última palavra! - até o preenchimento com valores simbólicos dos próprios fonemas. ${ }^{48}$

\footnotetext{
44 Idem, p. 60.

45 Alberto de Oliveira, crítica a Gouaches de João Barreira ( Revista de Portugal, vol. IV, 1892, p. 682)

${ }^{46}$ Carlos de Mesquita "O conde Robert de Montesquieu-Fezensac"(Arte, n 3 Coimbra, 1896, p. 119)

47 Julio Brandão, crítica a Alva de Alberto Pinheiro (Revista de Hoje, n 3, 1895, p. 116)

48 GUMARÃES, F. Simbolismo, Modernismo e Vanguardas. - Lisboa: Imprensa Nacional Casa da Moeda, 1982. p. 28 
O devir do sentido - que os simbolistas conseguiram mediante diversas figuras, entre as quais a suspensão e a metáfora alcançaram peculiar relevo - faz com que a poesia assuma uma dimensão simbólica, o que, aliás, já vimos que ocorre no soneto "Madalena" quando Camilo Pessnha se serve das metonímias simbólicas "seios" e "cabelos" em vários passos do poema. Mas nem toda crítica aceitou este caminho prosseguido pelos simbolistas. Manuel Laranjeira, por exemplo, afirma muito peremptoriamente que estes poetas "confundem deploravelmente símbolo com mistério, com tudo que há de vago e nebuloso". A este "radotage híbrido, desconexo como o fumo" contrapõe os "símbolos de idéias" de modo que a arte seja inseparável da concepção. ${ }^{49}$

Como já visto anteriormente, e fica claro nos execertos acima, os Simbolistas, ao contrário dos Decadentistas, deram grande importância à criação poética enquanto teoria. Assim como os românticos, eles têm uma de suas raízes da criação poética na "concepção prometeica do artista"50. Mas, ao contrário dos românticos, eles acreditam que somente o dom divino não é suficiente para a criação poética. Um entendimento metafísico, a explicação órfica da Terra como diz Mallarmé, a questão do enigma da vida, se fazem necessários. Além disso, acreditam menos na inspiração que na transpiração, dando grande valor ao conhecimento teorico, técnico e ao trabalho árduo do poeta - ao contrário dos românticos, para quem tudo é espontaneidade

A lírica está completamente dissociada da narração sob pena de perder sua pureza. A obra de arte pretende ser sublime e é por isso que, para o simbolista, a forma é tudo e é o único véu da realidade impalpável. Um novo uso da linguagem, bem como o uso das palavras, para expressar as relações entre o abstrato e o concreto se faz necessário. Gotthilf Heinrich von Schubert percebe que "o símbolo não deve ser uma abstração, mas deve ser concebido em termos de imagens físicas" 51 .

\footnotetext{
49 Idem. p. 31

50 PEREIRA, J. C. S. Decadentismo e simbolismo na poesia portuguesa. Coimbra: Centro de estudos românicos. 1975. p. 69

51 BALAKIAN, A. O Simbolismo. São Paulo: Perspectiva, 2007. p. 25 
A repurificação da linguagem, ao nível de cada palavra e das relações que se estabelecem entre ela e as outras, tem outro caminho: por um lado, despojar os vocábulos da sua significação actual, sobretudo naqueles mais marcados ou gastos pelo comércio quotidiano, para lhes restituir o seu original poder criador e mítico; por outro lado, levar a cabo uma renovação sintáctica que substitua, à relação lógica dos termos, uma relação poética pura, indissolúvel também da unidade do verso. A reivenção da linguagem assim operada reforça-se ainda por outros factores importantíssimos: o estabelecimento de complexa relacionação entre a consciência e as realidades subjectivas ou exteriores, numa vária funcionalidade da imagística e da simbologia; a pluridimensionação suscitada pela estranha construção do poema. ${ }^{52}$

Nesta sua inaudita preocupação formal (no melhor sentido), o Simbolismo entrega-se a uma alta valorizção da palavra em si, ou, antes, da beleza do significante. Não devemos deixar de apontar que tal valorização leva, por vezes, a um excessivo amor sensual da palavra assim encarada. ${ }^{53}$

Ainda no que tange a forma da poesia simbolista e a preocupação de seus poetas acerca da questão do símbolo no movimento, Seabra Pereira discute a questão da linguagem em Decadentismo e Simbolismo na literatura portuguesa (1975).

Um dos primeiros poetas a se ocupar da questão dos versos alexandrinos, houve até uma disputa intelectual com Eugénio de Castro acerca de quem deveria receber os louros pela inovação, Osório de Castro já era conhecedor dos poetas decadentistas e simbolistas e se colocava contra o Naturalismo. No segundo número da Boémia Nova, no qual improvisa uma pretensa carta "De Paris", Osório de Castro mostra sua adesão aos romancistas russos, cuja contribuiçao para a bancarrota do Naturalismo é bastante louvada pelo poeta.

52 PEREIRA, J. C. S. Decadentismo e simbolismo na poesia portuguesa. Coimbra: Centro de estudos românicos. 1975. p. 78

53 Idem, p. 89 
E um dia que litteratos curiosos revelaram ao Paris artista Gogol, Dostoiewsky, Pisemski, Turgueniew, sobretudo Tolstoï, , não pacificos phraseadores e sinzeladores, mas homens de vida agitada e martyr de uma causa sancta, liberadores de mujiks, deportados da Siberia, extranhamente comprehensivos, vindos de uma raça juvenil e soffrente, viu-se bem como abortara por completo a obra do naturalismo, como eram mesquinhos os pontos de vista artisticos dos últimos latinos. ${ }^{54}$

Assim, o poeta quer, a partir de seus escritos para a Bohemia Nova, incitar os poetas de Coimbra a forjarem uma nova escola, uma escola que seja capaz de provocar um estremecimento na arte portuguesa do fim do século. Chega até mesmo a fantasiar uma palestra com Dr. Topsius, o mesmo de $A$ Relíquia, para reforçar sua doutrinação aos novos poetas portugueses.

- Bem sei, bem sei. Mas, Topsius, hade concordar que esses poetas de Coimbra... somos ridiculos, hein? incomprehensiveis, torturados e sem espontaneidade, sem emoção? Pois façamo-nos já agora decadentes, symbolistas e banvillistas, ada vez mais empalhados, mais ridiculos, menos espontaneos... e mais tolos 55 .

Nesta mesma palestra Osório de Castro debate com Topsius a situação espiritual da atual geração de poetas que, amplamente influenciada pela ciência positivista, tem um veio bastante pessimista. Também há uma ponderação acerca de formas literárias, na qual Osório de Castro deixa clara sua predileção pela poesia e pelo romance psicológicos, segundo ele duas formas idênticas que tratam da alma tanto dos autores quanto dos leitores. "A litteratura não encontrará outras formas superiores a estas duas, cuja comprehensão e a fórmula serão a gloria deste século." ${ }^{6}$

54 CASTRO, A. O. De Paris. In: Bohemia Nova. Ano 1, n 2, 15 de Fevereiro de 1889. p. 27

55 CASTRO, A. O. Palestra com Dr. Topsius. In: Bohemia Nova. Ano 1, n 5, 22 de Março de 1889. p. 57

56 CASTRO, A. O. Palestra com Dr. Topsius. In: Bohemia Nova. Ano 1, n 5, 22 de Março de 1889. p. 58 
Apenas a poesia vencerá o romance, verá você, quando ela se tornar menos precisa, mais estranha e subtil, mais doente e menos lucida, como que uma melodia e como que um nevoeiro pacificante e vago... ${ }^{57}$

Em seu prefácio à edição das obras completas de Alberto Osório de Castro, publicadas em Lisboa em 2004, Seabra Pereira elenca, cronologicamente, uma série de temas decadentistas e simbolistas que são encontrados nas diversas obras do poeta.

Começando pelos temas comuns ao Decadentismo, já elencados pelo próprio Seabra Pereira em Decadentismo e Simbolismo na poesia portuguesa (1975) temos: um apelo ao Mistério, a religiosidade de inclinações católicas e a fé, o pessimismo derivado de um sentimento de Querer-Viver que, ao ser suprimido, os leva à frustração, o poente, o outono, o individualismo. Segundo Seabra Pereira (1975)

\section{É a época de Les Nevroses.}

Por isso, os decadentistas buscam, na senda de Baudelaire, 'le paradis artificiels'; descobrem os segredos dos perfumes raros e compósitos; inebriamse com as flores eas jóias desusadas, com a liturgia ostentatória e todas as manifestações sumptuárias; procuram, enfim, todos os caminhos que levam à fruição das sensações requintadas. ${ }^{58}$

O Oriente também aparece como a abordagem de um exotismo interiorizado, "feito de identificação com ambientes ou épocas de lascívia e decadência, de sangue e morte, de amorem et dolorem sacrum [...] O poeta, notemo-lo, dava assim pessoal contributo para uma atracção eopocal, fugindo de caminhos mais repetidos". ${ }^{59}$

\footnotetext{
57 Idem, ibidem.

58 PEREIRA, J. C. S. Decadentismo e simbolismo na poesia portuguesa. Coimbra: Centro de estudos românicos. 1975. p. 35

59 PEREIRA, J. C. S. Vestígios de verdade e beleza, para o retorno à luz. In:CASTRO, A. O., Obra poética. Lisboa: Imprensa Nacional Casa da Moeda, 2004. v. 1.p. 16. 
No que diz respeito ao tratamento dado às mulheres pelos autores decadentistas, Seabra Pereira afirma que, neste amor, há uma relação ambígua. Ao mesmo tempo que se sente fortemente atraído por essa mulher, o poeta decadentista também sente um impulso de afastamento, seja por um viés religioso que dá à beleza dela um caráter pecaminoso.

Este amor misticizante inscreve-se, naturalmente, no pano de fundo do brilho eclesial e litúrgico e rodeia-se da compensadora sensualidade dos perfumes invulgares, das cores imponentes, dos metais ou pedras raros, enfim, da preciosidade fulgurante. 60

O tratamento destes temas é mais facilmente encontrado em Exiladas, a primeira obra poética de Osório de Castro, do que em suas obras publicadas posteriormente, apesar de alguns deles estarem presentes ainda em $A$ Cinza dos Mirtos, seu segundo volume de poesias.

Em "Crisântemas", poema escrito em Óbidos no ano de 1893, um ano antes de sua partida para a Índia, encontramos o outono, o Oriente na figura do monte Fúsi-noYama (que fica no Japão), o exílio e as saudades, temas recorrentes na obra poética de Osório de Castro.

Tão longe do Fúsi-no-Yama,

No nosso outono, as exiladas

Crisântemas da terra em chama,

Florescem em tardes geladas.

Do seu canto natal de flama

Ainda mal desacostumadas,

Florescem em tardes geladas,

60 PEREIRA, J. C. S. Decadentismo e simbolismo na poesia portuguesa. Coimbra: Centro de estudos românicos. 1975. p. 39 
Tão longe do Fúsi-no-Yama!

E uma noite negra de lama,

As que viram noites doiradas,

Caem nas charcas, defolhadas...

Longe de tudo o que se ama,

Tão longe do Fúsi-no-Yama!61

No poema "Rosa Vermelha" são encontrados praticamente todos os temas citados acima; a mulher que desperta o desejo na figura de Laurinha, a presença do Oriente no caril que é o arroz com curry tão típico da Índia, o vermelho do hibisco e no sorriso rubro da Laurinha, as pérolas simbolizando as jóias e, por fim, a tarde, o vermelho do poente no céu de outono.

Ontem, Laurinha, a moue deliciosa

Da sua boca pequenina em til

Tinha uma graça púrpura, nervosa,

Como o florir do hibisco, e o caril.

E toda a noite, Laura, toda a noite, Desse passeio dum morrer d'Outubro,

Como um sonho acordado que tresnoite,

Eu só pensei no seu sorrir tão rubro.

Tons de sinopla e d'orpimento, a esparsa

Vaporação de pérolas do poente,

Punham na vaga paisagem garça

Uma tristeza espiritual e ardente!...

61 CASTRO, A. O. Exiladas. In: Obra Poética. - Lisboa: Imprensa Nacional Casa da Moeda, 2004 , v.1. p. 56. 
Ah! e ao clarão nevrálgico, indeciso,

Vi resplender, aureolado e absorto,

A floração divina do seu riso

Abrindo à luz convulsa do sol morto.

Tarde outoniça, esplêndida e sombria!

Luz histeral de um dolorido amor!

Doce queimor dos beijos! Harmonia

Do céu vermelho e do sorriso em flor!62

No que tange o Simbolismo, movimento que vem logo em seguida do Decadentismo e que o engloba, os temas permanecem bastante parecidos. O que nele aparece de novo é um sentimento de Sehnsucht, semelhante ao do Romantismo alemão, no qual há muito presente a noção da genialidade do poeta.

Também, ele, escritor, se via apossado por algo de indefinívele impulsivo, aspiração inquieta de um além, semelhante à Sehnsucht romântica, e tinha de viver o apelo de uma realidade transcendente, mas envolvendo o mundo. ${ }^{63}$

Um das raízes da atitude do Simbolismo perante a criação poética mergulha na concepção prometeica do artista, tal como fora amada pelo Romantismo. Porém, se na literatura romântica alemã e inglesa (e também em certo romantismo francês) esta concepção se traduz não só na condenação das regras, mas ainda no menosprezo pelo labor lumioso da consciência e da inteligência, no Simbolismo vamos encontrar uma posição diferente. Nele, pode dizer-se que a contribuição romântica é assumida como dado natural, enquanto reconhecimento da existência em toda a criação poética, de um elemento inicial

62 CASTRO, A. O. Exiladas. In: Obra Poética. - Lisboa: Imprensa Nacional Casa da Moeda, 2004, v. 1. p. 64.

63 PEREIRA, J. C. S. Decadentismo e simbolismo na poesia portuguesa. Coimbra: Centro de estudos românicos. 1975. p. 63 
inalcançável pelo esforço voluntário e artífice; contudo, dado o advento de uma doutrina intelectualista da criação poética, que surge primeiramente em Poe e em Baudelaire, ela é rejeitada enquanto afirmação unilateral do arracional e do extático como valores criativos e realizadores. ${ }^{64}$

É da singular convergência de espírito de poesia pura e de elevada missão cognoscitiva (explicação órfica da Terra e psicologia intuitiva das profundezas) que resulta a específica configuração da poética e da lírica simbolistas. ${ }^{65}$

Tendo em vista o que nos diz Seabra Pereira sobre as principais características do Simbolismo e que elas podem ser melhor encontradas a partir de $A$ Cinza dos Mirtos, voltemos nossa atenção para este segundo volume de poemas, bem como para As Flores de Coral, o terceiro volume publicado. É importante ressaltar que o que antes foi encontrado em Exiladas não deixa de estar presente nas obras seguinte pelo simples fato de serem o Decadentismo e o Simbolismo movimentos bastante parecidos. Deste modo, o Oriente, o poente, o outono, o vermelho, entre outros já abordados anteriormente, não ficam de fora de $A$ Cinza dos Mirtos bem como de $A s$ Flores de Coral.

Temas recorrentes da obra de Osório de Castro como um todo, tais como a brevidade da vida, a imanência da morte, a implacabilidade do tempo e as saudades também estão presentes, tanto no segundo quanto no terceiro volumes de poemas do magistrado português.

Seabra Pereira afirma que a publicação de um terceiro volume de poesias de Osório de Castro se fez necessária pois todo o potencial intelectual e artístico do poeta não havia sido explorado o suficiente em $A$ Cinza dos Mirtos. Segundo o crítico, é em Flores de Coral que podemos perceber também o amadurecimento de Osório de Castro através de um gosto pela erudição, que está presente nos volumes anteriores mas toma mais corpo neste último. Junto com este amadurecimento e acentuamento

64 Idem, p. $69-70$

65 Idem. p. 74 
de seu potencial, há um aprofundamento no que tange o tratamento do Oriente em sua obra.

O mais notável das Flores de Coral parece-nos residir naquela poesia - neo-romântica, sim, mas de origem simbolista - de recuperação da candura primordial, ora pelo viés do impressionismo exótico, ora pelo viés do infantilismo: é a arte anti-intelectualista e antidiscursiva (com as recorrências e os paralelismos prosódico-versificatórios a regerem a associação de imagens à margem dos nexos lógicos habituais) de poemas inspirados em lendas timorenses e de poemas infantis $[\ldots]^{66}$

O grande amigo de Osório de Castro, Camilo Pessanha, escreve uma breve crítica quando da publicação de Flores de Coral na qual aborda não apenas a qualidade dos poemas contidos no volume mas também sua estética, que diz ser a mais variada. Osório de Castro adota diversas formas de métrica e estrofes, vai desde as quadras até as odes, passando por sonetos parnasianos que, segundo Pessanha, rivalizariam com os melhores de Gonçalves Crespo e confirmam o que diz Seabra Pereira em relação ao aprofundamento que o poeta faz no campo da erudição.

Em Flores de Coral encontramos novamente a questão da brevidade da vida, da iminência da morte, da passagem do tempo, tão presente em Exiladas e A Cinza dos Mirtos, mas desta vez não necessariamente advindas da temática decadentista e simbolista, que aborda tais questões por seu veio pessimista mas pela idade que tem o autor quando da publicação do volume. Aos 40 anos Osório de Castro já se permite olhar para trás afim de avaliar o caminho até então percorrido e sentir certas saudades, tema também sempre presente em suas obras anteriores, além de tecer considerações sobre o futuro, não muito longo, que o aguarda. Apesar disto, seus versos não têm um

66 PEREIRA, J. C. S. Vestígios de verdade e beleza, para o retorno à luz. In: CASTRO, A. O. Obra poética. Lisboa: Imprensa Nacional Casa da Moeda, 2004. v. 1. p. 23 
tom de "pranto de fúnebres condolências sobre as ilusões perdidas"67.

No tocante à questão das rimas, como aparece na fala Seabra Pereira em Decadentismo e Simbolismo na Literatura Portuguesa, temos a impressão de que elas são abominadas pela poesia simbolista mas não chegam a ser abolidas, apesar de terem sua função na poesia amplamente discutida. No que diz respeito ao uso da rima na obra poética de Osório de Castro, encontramos na dissertação Alberto Osório de Castro, ensaio bio-bibliográfico e crítico de Ana Maria Oliveira os três tipos mais frequentemente usados pelo poeta. São eles, as rimas emparelhadas, formadas por versos emparelhados:

Gritos de morte, pragas de furor,

E as labaredas tresdobrando o horror...

- É entrada Goa! Santa Catarina,

Rogai por nós a vossa mãe divina!

Dizei, Luís Preto, a Afonso de Albuquerque

Que desça presto, e toda a cava cerque.68

As rimas cruzadas, formadas por versos que se alternam, as mais comuns em sua obra:

Pálidas rosas de Chimbel,

Coitadas de elas, a murchar,

Sem que à sua alma o aroma e o mel

As abelhas vão procurar69

67 PESSANHA, C. As "Flores de Coral" de Alberto Osório de Castro. In: QUADROS, A. Org. Obras de Camilo Pessanha, v. II.

68 CASTRO, A. O. A Cinza dos Mirtos. In: Obra Poética. - Lisboa: Imprensa Nacional Casa da Moeda, 2004, v. 1. p. 233.

69 CASTRO, A. O. A Cinza dos Mirtos. In: Obra Poética. - Lisboa: Imprensa Nacional Casa da Moeda, 2004, v. 1. p. 160. 
As rimas interpoladas, muito comuns em sonetos, são formadas pela rima entre o primeiro e quarto versos e segundo e terceiro versos de uma estrofe:

Moro numa água-furtada,

Mais perto das cotovias,

Numa trapeira encantada

De sonhos e fantasias. ${ }^{70}$

A metrificação constitui outro problema, há uma corrente que tende para uma total libertação da metrificação enquanto que uma outra, apesar de alterar o verso tradicional, não the nega nenhum de seus elementos fundamentais. "Também nos metros, os simbolistas, quer pela prática poética, quer pelos escritos teóricos, fazem patrimônio seu todas as conquistas que a audácia decadista alcançara"71.

Inclusive, como deixa claro Seabra Pereira no prefácio que escreve às Obras Completas do poeta, Osório de Castro é largamente influenciado pelas métricas e formas orientais ao fazer uso do launim, uma forma de poema indiana, pantum e pantum malaio, tankás e kai-kai japoneses.

Ana Maria Oliveira, em sua dissertação, chega mesmo a afirmar que "O estudo da métrica na poesia de Alberto Osório de Castro, poderia ser o assunto de uma tese [...] Podemos afirmar, mesmo, que ele empregou todos os metros conhecidos"72.

Em vista do engajamento que tem o poeta em seus escritos para Boémia Nova no que diz respeito à causa dos versos alexandrinos e à inovação da métrica, com a apologia que faz aos autores russos que vão contra o Naturalismo, ao qual Osório de Castro veementemente se opõe, há ainda a abordagem de diversos temas comuns

70 CASTRO, A. O. A Cinza dos Mirtos. In: Obra Poética. - Lisboa: Imprensa Nacional Casa da Moeda, 2004, v. 1. p. 194.

71 PEREIRA, J. C. S. Decadentismo e simbolismo na poesia portuguesa. Coimbra: Centro de estudos românicos. 1975. p. 91

72 OLIVEIRA, A. M. da C. Alberto Osório de Castro, ensaio bio-bibliográfico e crítico. Tese (Licenciatura em Filologia Românica). Faculdade de Letras, Universidade de Lisboa. Lisboa, 1959. P. 176 
aos movimentos Decadentista e Simbolista em sua obra poética, o que faz com que ela seja facilmente situada dentro de ambos movimentos. 


\section{CAPÍTULO 3}

\section{A representação do Oriente e outros temas na obra de Alberto Osório de Castro.}

\subsection{Oriente como mito e não tema}

A abordagem do Oriente na literatura portuguesa não constitui novidade alguma. Álvaro Manuel Machado, em seu O mito do Oriente na literatura portuguesa (1983) fala sobre uma preferência do português pelo Oriente, mais precisamente pela Índia, em detrimento da África. O próprio Osório de Castro, como magistrado, permanece muito pouco tempo em um posto na capital de Angola, de onde pede transferência para o Timor por vontade de retornar ao Oriente.

Apoiados na distinção faz Álvaro Manuel Machado entre mito e tema em O mito do Oriente na literatura portuguesa (1983), queremos entender se Osório de Castro, em sua obra poética, dispensa ao Oriente o tratamento de mito ou de tema quando o aborda.

Segundo Machado:

[...] tema se circunscreve à 'explicação' imediata, descritiva do texto literário, ordenando-o estritamente em função da diacronia literária (ainda que numa perspectiva comparativista), o mito eleva o tema a um nível de catarse (no 
sentido propriamente aristotélico), tornando-o um elemento sincrônico. [...] Tratase muito concretamente, muito exactamente, da elaboração 'cultural' de um tema tornado propriamente mito. [...] Em suma: trata-se de um tema derivado dessa 'memória colectiva' que conserva e transmite acontecimentos históricos tornados exemplares, esse 'inconsciente colectivo' jungiano. ${ }^{73}$.

Para melhor elucidar e justificar o uso do termo mito no título de seu ensaio e como ele se contrapõe a tema, Machado se vale de um texto escrito por ele mesmo em colaboração com o Prof. Daniel-Henri Pageaux:

[...] na origem de todo o mito das nossas sociedades está uma situação de manque; é o que poderia corresponder, nas sociedades sem escrita e sem história, à 'violência fundadora'. Para preencher este manque, este vazio, a sociedade constrói e desenvolve um mito: um cenário mítico que vai dar sentido ao mundo, que vai recriar a vida do grupo, que vai dar coerência ao grupo. [...]

[...] da mesma maneira que o mito assegura uma determinada coerência ao grupo que o aceita, também dá coerência ao texto: de fundador nos planos histórico, social, religioso, o mito torna-se assim produtor de texto. ${ }^{74}$

Segundo Machado, todo mito se origina de uma situação de vazio como uma maneira de explicar e dar sentido ao mundo. Então, temos que, enquanto o tema se resume a uma explicação imediata e descritiva de um texto literário, seu assunto por assim dizer, o mito se encarrega de transformar este tema em algo que é passível de apropriação cultural.

Assim, de acordo com Machado, podemos considerar que grande parte da abordagem do oriente na literatura portuguesa tem o caráter de mito e não de tema, já desde a época em que João de Barros (1496 - 1570) e Damião de Góis (1502 -

\footnotetext{
73 MACHADO, A. M. O mito do Oriente na literatura portuguesa. - Lisboa: Instituto de cultura e língua portuguesa, 1983. p 12.

74 MACHADO, A. M. e PAGEAUX, D. Literatura Portuguesa, Literatura Comparada e Teoria da Literatura. Ed. 70, Col. "Signos", Lisboa, 1982, p. 95 e 97.
} 
1574) escreveram suas obras sobre o Oriente, no caso de ambos um Oriente que se restringia principalmente à Índia, uma Índia mais idealizada do que concreta, construída por eles para seus leitores a partir de seus textos.

O homem português tem a paixão pela descoberta, pelo novo e vai ao Oriente não apenas por razões político-econômicas mas também movido pela curiosidade humanista, pelo que é estranho a esse homem ocidental, fruto das heranças clássica e cristã. Soma-se a isto o apelo do longínquo, que, para uns, surge como um mundo utópico e cuja influência de Camões sedimenta a imagem mítica do Oriente na literatura portuguesa.

E desde logo, creio, deparamos com o seguinte: nos Lusíadas, o mito do Oriente, ou melhor, o que podemos considerar potencialmente mítico no tema do Oriente, está totalmente dependendente quer da mitologia clássica quer da mitologia nacionalista, esta dependendo por sua vez daquela, isto mesmo nas raras passagens em que vem ao cima o elemento confessional. ${ }^{75}$

O convencionalismo mitológico é aqui evidente - e assim, o mito, o mito literariamente elaborado, não chega a impor-se. Dir-se-ia que Camões tenta recuperar nos Lusíadas, através do artifício mitológico clássico, o tal mito nacionalista historicamente fundado de um Oriente, em particular de uma Índia de outrora, perdida para sempre, essa tal Índia de guerreiros impolutos opostos aos vis comerciantes que Diogo do Couto também imagina. ${ }^{76}$

O mito do Oriente, que encontra sua apoteose em Camões, fica adormecido até o século XVII, quando renasce junto ao pré-romantismo, especialmente com a poesia de Bocage, que herda de Camões "a mitologia nacionalista voltada para o passado."77

\footnotetext{
75 MACHADO, A. M. O mito do Oriente na literatura portuguesa. Lisboa: Instituto de cultura e língua portuguesa, 1983. p. 53.

76 Idem, p. 55.

77 Idem, p. 64 
Em Bocage o mito do Oriente "tomará sobretudo a forma de uma sistemática, obsessiva idéia de decadência histórica de Portugal."78

Ao contrário de muitos dos escritores que se debruçaram sobre o mito do Oriente, Bocage teve a oportunidade de escrever sobre ele in loco, quando partiu para a Índia em 1786 ao ser nomeado guarda-marinha.

Por outro lado, como o Camões d'Os Lusíadas, Bocage só evoca a civilização oriental em breves imagens de uma exótica e infernal natureza, para exprimir um ocidentalismo que o leva a repudiar em termos dogmáticos tudo o que se opõe à religião cristã. ${ }^{79}$

Ao ser recuperado, durante o pré-romantismo, o mito do Oriente na literatura ressurge junto com o gosto por viagens como a expansão do eu. Contudo, este sentimento se inicia através de viagens reais, como as de Camões e Bocage, para logo passar ao imaginário. Todos os autores que escrevem sobre o Oriente lá estiveram, alguns de fato, outros apenas em pensamento, como é o caso do francês Baudelaire. "Referi atrás sua viagem estática, a sua procura interior do Oriente do Ocidente." 80

É a partir deste momento, da escrita sobre o mito do Oriente tanto sob a perspectiva distante de quem fez a viagem apenas em pensamento e imaginação, quanto do ponto de vista de quem pôde ter a vivência in loco, que entra em cena o que Edward Said chama de Orientalismo.

O Oriente era praticamente uma invenção européia e fora desde a Antiguidade um lugar de episódios romanescos, seres exóticos, lembranças e paisagens encantadas, experiências extraordinárias. [...] .... Orientalismo, um modo de abordar

\footnotetext{
78 Idem, ibidem.

79 Idem, p. 67

80 Idem, p. 77 
o oriente que tem como fundamento o lugar especial do Oriente na experiência ocidental européia. ${ }^{81}$

Para Said, o Oriente é uma criação européia e concebe "o Orientalismo como um estilo ocidental para dominar, reestruturar e ter autoridade sobre o Oriente."82 $O$ Orientalismo surge então como uma forma de exercer o domínio que é necessário ter sobre o espaço oriental, seja ele geográfico ou imaginário.

Com base no que foi visto até agora, passamos ao que é o ponto de maior interesse deste trabalho, o tratamento que Alberto Osório de Castro dá ao Oriente em sua obra poética. Já sabemos que o Oriente surge na condição de mito e não como tema, pelo fato de o poeta não se ater unicamente à explicação imediata e descritiva mas se apropriar do Oriente para tratá-lo subjetivamente.

\begin{abstract}
Em primeiro lugar, quase todo escritor do século XIX (e o mesmo vale para escritores de períodos anteriores) era extraordinariamente consciente do fato do império: esse é um assunto não muito bem estudado, mas um especialista moderno no período vitoriano não levará muito tempo para admitir que heróis culturais do liberalismo como John Stuart Mill, Arnold, Carlyle, Newman, Macaulay, Ruskin, George Eliot e até Dickens tinham opiniões definidas sobre raça e imperialismo, todas elas bem representadas em seus escritos. ${ }^{83}$
\end{abstract}

Said trata aqui, especificamente, de autores ingleses, mas esta descrição pode ser perfeitamente aplicável aos autores portugueses do mesmo período e no caso de Osório de Castro, na condição de funcionário da coroa portuguesa, ela encaixase perfeitamente. Sabemos ser isto verdade através das palavras que o próprio poeta usa para falar sobre a arte oriental, neste caso específico a chinesa, que encontra no museu particular do amigo Camilo Pessanha ao visitá-lo em Macau.

81 SAID, E. W. Orientalismo: O Oriente como invenção do Ocidente. - São Paulo: Companhia das Letras, 2007. p. 27

82 Idem, p. 29

83 Idem, p. 43 
As pinturas chinesas do Museu de Camilo são um pouco, aos meus olhos de Ocidental, como esta poesia singular, que em mim evoca um infindo abismo, de translúcido vácuo. Também isto tem encanto... ${ }^{84}$

A partir desta descrição fica claro que o poeta tem plena consciência de sua condição de ocidental ao analisar a arte oriental e todo o ambiente que está ao seu redor.

Então, como Osório de Castro se apropria do Oriente que estava à sua volta? A razão de ter escolhido o mito do Oriente como uma das figuras centrais de sua obra, bem como a efemeridade da vida, a morte, as saudades e o outono, se deve não apenas a motivos particulares, por questões familiares já abordadas anteriormente como a avó que nasceu na Batávia, mas também ao fato de estar o Oriente em voga, sendo um dos elementos que caracteriza tanto o Decadentismo quanto o Simbolismo. Seu grande amigo Camilo Pessanha não apenas escreveu sobre a China mas também traduziu obras chinesas para o português durante o tempo em que esteve em Macau.

O Oriente aparece em sua obra em diferentes momentos, desde antes de deixar Portugal, quando, por exemplo, ainda está em Óbidos e escreve o poema "Crisântemas" (1893), no qual fala sobre o monte Fúsi-no-Yama e as crisântemas que lá se encontram. Este, um claro exemplo do Orientalismo estático, como o de Baudelaire, do poeta que não teve a chance de estar no Oriente sobre o qual escreve e que, portanto, pode ser e é como exige sua imaginação. Ainda mais neste caso, pois escreve sobre o Japão, um país que Osório de Castro não teve a oportunidade de conhecer, ao contrário da China, nem mesmo durante a época em que morou na Índia.

Para uma primeira abordagem da presença do Oriente na obra de Alberto Osório de Castro foi escolhido o poema 'Sâti", parte integrante da sua segunda obra publicada, $A$

84 LANCASTRE, M. J. de. Camilo Pessanha, cartas a Alberto Osório de Castro, João Baptista de Castro e Ana de Castro Osório. Lisboa: Imprensa Nacional Casa da Moeda,1984. p. 126. 
cinza dos mirtos. Esse segundo volume de poemas do magistrado português não apenas foi publicado em Goa no ano de 1906 como também teve grande parte de seu conteúdo produzida lá e, com isso, pôde se apropriar de temas indianos, entre eles o que parece ser a grande obsessão ocidental quando o assunto em pauta é a Índia: sati ou suttee.

Antes que se possa dar início a uma análise mais profunda do poema, há que se dedicar certa atenção ao termo sati, que ao poema empresta seu nome. Não é possível precisar a data em que este costume iniciou-se, mas de acordo com a mitologia indiana ele se origina a partir de uma deusa de mesmo nome. É no Ramayana, a mais famosa epopéia indiana, que narra a história do príncipe Rama e da princesa Sita, que se encontra a história da deusa Sati.

Filha de Daksha, Sati, por isso também conhecida como Dakshayani, é instigada por seu avô, ninguém menos que o deus Brahma, a ir em busca de Shiva. O pai de Daksha quer humilhá-lo pois Shiva o havia insultado anteriormente, quando riu de Brahma ao descobrir que este havia cobiçado sua própria filha. Brahma jurou seduzir Shiva, um deus de natureza asceta, para dentro dos mistérios da paixão carnal e então encoraja sua neta a ir tentá-lo.

Apesar de serem o ascetismo e a lealdade as principais características atribuídas à Sati e aquelas pelas quais Shiva se deixa conquistar, ela também costuma ser descrita como uma mulher muito bonita. Quando Dakshayani pede para que Shiva case-se com ela, ele aceita prontamente pois, em um momento que não pode ser precisado, descobrira a presença do desejo (dharma), que a tornara extremamente atraente.

É Brahma quem oficia a cerimônia do casamento. Em outra circunstância, muito provavelmente por causa dos hábitos estranhos e da aparência esquisita de Shiva, se inicia uma tensão entre sogro e genro. Marido e mulher retiram-se então para a montanha de Shiva e lá vivem por muitos anos, até que Sati recebe a notícia de que haveria uma festa - há versões que relatam um ritual de imolação ao invés de uma 
festa - de seus pais, para a qual ela não recebera convite. Julgando essa falta como uma formalidade desnecessária entre familiares, Dakshayani decide comparecer mesmo assim. Lá chegando é inicialmente ignorada por seu pai, que depois se dirige a ela com a finalidade aparente de apenas insultar Shiva. Não suportando os insultos destinados a seu marido, Sati se mata, jogando-se em uma fogueira como prova de sua lealdade e como forma de salvar a honra de seu amado.

Ao receber a notícia da morte de sua mulher, Shiva se enraivece e cria Virabhata - em certas versões da história cria também outras criaturas ferozes. Eles então se dirigem para a residência de Daksha onde travam uma batalha com os deuses que participavam da festa. Acredita-se que Daksha tenha morrido durante a luta.

Com seu sacrifício, Sati provoca um conflito entre dois campos opostos da religião hindu: o ascetismo, representado na figura de Shiva, e a ligação profunda com a Terra na figura de Daksha. Inicialmente poderia-se pensar que esse choque seria destrutivo, mas, por fim, acaba sendo benéfico, ao fazer com que Shiva, inicialmente alheio ao mundo, se volte um pouco para a terra.

É desse ato desesperado de Sati, o de atirar-se à fogueira para salvar a honra de seu marido e assim provar sua lealdade a ele, que se originaria o costume de imolarem-se nas piras funerárias de seus maridos as viúvas indianas, fosse essa a vontade delas ou não. No entanto, há que ser cauteloso no emprego do termo sati. Enquanto que no mundo ocidental a palavra é empregada para se referir ao ato de autoimolação na fogueira, na Índia é usado por muitos hindus para se referir à mulher que se atirou à pira. Assim, os termos viúva e sati são excludentes na cultura indiana, uma viúva é uma mulher que continua viva mesmo após a morte do marido, enquanto que a sati é que a se imolou na pira funerária do marido. Fala-se aqui de designações genéricas, pois há muitas exceções. Na região de Goa, por exemplo, o termo para a designação de uma viúva é bodki. A cautela é recomendada também no que tange a difusão desse costume na sociedade hindu. Ao contrário do que se acredita no 
Ocidente, a imolação da mulher na pira funerária do marido costumava ser a exceção e não a regra.

Contudo, é o sentimento de absurdo provocado por este rito na mente ocidental que faz com que ele se torne tema recorrente em obras que têm a Índia por cenário, desde antes de Alberto Osório de Castro até os dias de hoje. Recentemente a questão do sati esteve presente na novela da Rede Globo, Caminho das Índias, de autoria de Gloria Perez, transmitida entre janeiro e setembro de 2009. Por se tratar de uma obra de ficção, o sati não foi posto em debate, mas apenas mencionado como um costume indiano antigo e cuja prática não é mais aceita ou bem vista pela sociedade atual. $O$ tema vem à tona através da personagem de Laura Cardoso (Laksmi), que faz o papel de uma viúva amargurada porém de sorte, que lamentava e justificava sua amargura pelo fato de ter sido impedida de se imolar na pira funerária de seu marido após a morte dele muitos anos antes - a razão do impedimento teria sido a gravidez de seu único filho, Opash, personagem de Tony Ramos. No entanto, não fica claro como, e nem porque, ela não é excluída da sociedade, destino reservado às viúvas que não se imolam na pira funerária do marido, se fosse respeitada a antiga tradição. Pelo contrário, ela não apenas continua morando com a família como também consegue casar o filho (tarefa bastante difícil, uma vez que o filho da viúva seria considerado como seu sucessor e traria mau agouro para quem se aproximasse).

$\mathrm{Na}$ literatura indo-portuguesa a questão do sati aparece no romance Bodki de Agostinho Fernandes, de 1962, romance, ao que tudo indica, auto-biográfico, no qual o autor, médico recém-formado, conta sua experiência profissional em uma pequena vila no interior de Goa. Como pano de fundo da narrativa há a figura e a história da Bodki, uma viúva que é excluída da sociedade por ter se negado a atirar-se à pira funerária do marido e que vive com sua filha Kamala, igualmente rejeitada pelos habitantes da aldeia onde vivem.

Apesar de o rito já haver sido abolido pelos portugueses logo nos primeiros anos da conquista, em 1555, o preconceito contra as viúvas permaneceu me Goa. Na Índia 
o embate entre colonizador e colonizado é ainda mais delicado do que foi em outras colônias portuguesas. Com isto não se quer dizer que esta relação tenha sido fácil no Brasil ou na África. Os colonizadores não foram vistos com bons olhos em qualquer lugar onde chegaram, impondo seus costumes como os únicos aceitáveis. Porém, na Índia o colonizador contava com o agravante do sistema de castas, no qual jamais terá um lugar de prestígio de fato, pois, vindo de fora, não tem uma casta definida. Tornouse bem mais difícil a possibilidade de ele fazer parte da sociedade indiana em pé de igualdade com um hindu de casta elevada.

Ainda em 1962, ano da publicação de Bodki, apesar de já ser legalmente abolida em toda a Índia, a prática do sati continuava presente na sociedade indiana, especialmente nas regiões mais rurais. No romance, a Bodki não tem nome. A partir do momento em que escolhe não ser sati, ela se torna bodki e sua identidade anterior é completamente anulada. Sua filha, no entanto, apesar de ser conhecida por todos como a filha da bodki (não há na aldeia quem não saiba de quem ela é filha), consegue ter uma identidade própria ao ser referida por seu nome: Kamala. Apesar de todos os seu esforços, que não foram poucos, o médico não apenas não consegue mudar a mentalidade dos locais, que ateiam fogo à cabana da Bodki, como se torna uma pessoa indesejada depois que Kamala se mata, jogando-se na pira funerária do namorado que a engravidara, pouco depois de sair de seu consultório. Tendo sido associado ao mau agouro, é considerado o sucessor da bodki:

Sim, e isso complica o caso ainda mais. Kamala visitou-o momentos antes de se sacrificar, não é verdade? Sabe como interpretarão esse facto? Dirão que ela passou ao doutor todos os seus poderes maléficos, toda a legião dos seus espíritos malignos. Que o tornou seu herdeiro, seu sucessor. ${ }^{85}$

A única saída que resta ao médico é ir-se embora da aldeia, já que os locais preferem se deixar comer pela doença a se tratarem com um médico sobre cuja

85 FERNANDES, A. Bodki. In: DEVI,V. \& SEABRA, M. A Literatura Indo-Portuguesa. Lisboa: Junta de Investigações do Ultramar, 1971. p. 210-11. 
cabeça paira a nuvem da desgraça trazida pela bodki. Contudo, apesar de não acreditar nas superstições daquela gente, ao embarcar no trem que o levaria para longe dali, recebe numa carta de seu pai a notícia de que seu cunhado morrera em um acidente, deixando sua irmã, Lena, grávida e viúva. É com tristeza que o doutor constata que "Agora Lena é uma bodki."86

Ainda sobre a questão do sati em Goa, sob uma perspectiva prática, encontramos em The many faces of Sundorem, women in Goa, de Fatima da Silva Gracias, a informação de esta era uma prática comum na região. As mulheres que se recusavam a imolar-se nas piras funerárias do maridos eram, muitas vezes, levadas a fazê-lo à força depois de serem intoxicadas com ópio e embriagadas. Se elas concordassem de bom grado, uma grande festa com comida local e bastante bebida alcóolica típica da região, a urraca, era dada e ela era acompanhada com música até a pira, onde deveria se despir de suas roupas e jóias. Relatos jesuítas contam que esse costume prevaleceu até depois do século XVI.

Apesar de às mulheres católicas não ser reservado o mesmo destino cruel que era reservado às viúvas indianas em geral, "as viúvas eram tratadas com desumanidade após a morte de seus maridos" 87 e, portanto, sua condição não era muito melhor. A elas era permitido casarem-se novamente, mas apenas uma pequena parcela arrumava um novo marido, pois tal ato não era visto com bons olhos pela sociedade local. Além disso, na eventualidade de um segundo casamento, a viúva perdia todo e qualquer direito sobre a propriedade que herdara do marido. Em geral elas apenas mantinham uma vida reclusa, vestiam-se de preto e não usavam jóias em sinal de sofrimento pela condição de viúva.

Também o famoso poeta alemão, Johann Wolfgang von Goethe escreve, em 1797, uma balada sobre o sati, "Der gott und die Bajadere", poema que tem como elemento central o deus indiano Shiva (no poema chamado de Mahadöh, Mahadeu, um dois seis

\footnotetext{
86 Idem, ibidem.

87 "Widows were inhumanly treated after the death of their husbands" In: GRACIAS, F. S. The many faces of Sundore: Women in Goa. Panjim: Surya Publications, 2007. p. 16 
nomes de Shiva) e o sati de uma jovem bailadeira apaixonada por ele.

Num exemplo de literatura mais conhecida do público em geral do que um romance indo-português, temos ainda o caso de $A$ volta ao mundo em 80 dias, do francês Júlio Verne, em que o sati aparece talvez como uma das mais importantes experiências vividas por Phileas Fogg e Chavemestra durante sua passagem pela Índia. Depois de ser desafiado pelos outros cavalheiros membros do Reform Club de Londres, Phileas Fogg decide, junto com seu criado Chavemestra, que dará a volta ao mundo em 80 dias. Durante sua aventura, Mr. Fogg, juntamente com seus outros companheiros de viagem, dentre eles seu fiel escudeiro Chavemestra, um outro gentleman, Sir Francis Cromarty, e um local de origem parse que se encarrega de guiá-los através da selva indiana, deparam-se com um cortejo fúnebre de um Rajá, cuja viúva seria imolada contra sua própria vontade. Aouda, uma jovem indiana órfã de origem parse, fora praticamente obrigada a casar-se com um Rajá muito mais velho do que ela e que morre três meses depois das núpcias. Não nutrindo qualquer forma de afeto por esse marido que mal conhece, a jovem viúva não tem o menor desejo de imolar-se em sua pira funerária. Quando questionado por Mr. Fogg qual seria a origem da viúva, o parse Ihe informa todos os detalhes já elencados acima além de enfatizar a criação e educação inglesa que a viúva do Rajá recebera. "Indiana de uma beleza notável, de raça parse, filha de ricos negociantes de Bombaim, ela recebera nessa cidade uma educação absolutamente inglesa, e, por suas maneiras, por sua instrução, passava por uma européia." 88

A importância que se dá ao fato da educação britânica recebida pela moça só vem reforçar o fato de que os ocidentais consideram o rito do sati um absurdo incomensurável. Fosse a viúva uma indiana não apenas de nascimento mas também de criação, talvez a própria não se opusesse com tanta veemência ao destino que the era imposto (o sati havia sido proibido pelos ingleses mas ainda era considerado uma prática aceita pelos hindus e em certos casos a permissão para sua execução era

88 VERNE, J. A volta ao mundo em oitenta dias. Trad. Antonio Caruccio-Caporale. - Porto Alegre: L\&PM, 2010. 
concedida dependendo da insistência da viúva em imolar-se na pira do marido) e nem os estrangeiros em questão se indignassem tanto ao tomarem conhecimento do costume local. Porém, uma vez que há a identificação cultural de parte dos ingleses com a suposta vítima, eles não medem esforços para enfrentar os indianos e salvar Aouda.

O assombro que os acomete no momento da descoberta do sentido do rito é tamanho que quase os faz perder a noção do perigo e cometer um ato impensado para livrar a quase compatriota de um destino considerado por eles (e nisso inclui-se a inglesa por educação) terrível e praticamente inevitável. No entanto, é curioso o fato que, uma vez salva Aouda, Mr. Fogg parece não importar-se muito com o destino que a aguarda depois. É apenas quando o outro gentleman o informa que Mr. Fogg deveria tornar-se responsável pela viúva, garantindo que ela chegasse a salvo pelo menos a uma terra estrangeira, na qual os costumes e as leis hindus não tivessem qualquer valor, que ele concorda em levá-la junto com ele para Hong Kong.

Como visto até agora, evidencia-se que o sati é um tema recorrente entre os ocidentais ao tratarem do Oriente. A figura da bailadeira é outro tema que instiga a curiosidade ocidental, tanto que até autores goeses que escrevem para o público ocidental, como Vimala Devi e Nascimento Mendonça, as incluem em seus escritos às vezes como figura central.

No glossário ao fim de A Cinza dos Mirtos, é encontrada uma definição do termo bailadeira na qual também se encontra a forma bailadora, admitida como forma do masculino bailador, que designava os homens que as acompanhavam com instrumentos e o canto durante as apresentações. Ainda segundo esta definição, elas eram as hieródulas dos templos bramânicos e na Índia são conhecidas por Dêva-Dassi que quer dizer escrava dos deuses.

Em The many faces of Sundorem (2007) Gracias diz que condições sócioeconômicas forçavam as bailadeiras a oferecer seus serviços aos sacerdotes do templo e homens de classe social mais altas. Alguns destes homens as mantinham 
como suas amantes e ofereciam doações ao templo a que elas estavam vinculadas. Seu status era diferente do das prostitutas, sendo algumas delas filhas ilegítimas de brâmanes. A maioria delas era muito bonita e eram alfabetizadas em marati, algumas até mesmo em sânscrito, mas eram olhadas com desprezo pela sociedade por dançarem em público.

Havia quatro categorias de mulheres que serviam no templo: Colvontas, Chedvans, Deulinas e Bandens. Na Índia britânica essas mulheres eram conhecidas por Devadassis. Na sociedade Goesa o nome genérico para tais mulheres era naiquins. A filha de uma naiquin era chamada de cedunale e era iniciada na profissão através de uma cerimônia chamada Xens/Chens/Sesa. A menina era apresentada para a cerimônia por um homem proeminente na vila que depois tinha o direito de manter relações com esta menina depois que ela atingisse a puberdade.

A cerimônia do Chens era como um casamento mas com algumas diferenças. Nesta cerimônia de iniciação a menina era casada com um objeto, geralmente uma flor ou outra menina vestida como homem. O Chens também era conhecido como atlaulim, que significa acariciar ou tocar com as mãos. Viúvas ricas, incluindo as grávidas, entravam na profissão quando mandadas para fora de casa pela família de seus finados maridos. Algumas mulheres abandonadas pelos maridos vivos também se juntavam à categoria. ${ }^{89}$

89 There were four categories of women who performed duties at the temple: Colvontas, Chedvans, Deulinas and Bandens. In British India, these women were known as Devadasis. In Goan society, the generic name for such womens was naiquins. The offspring of naiquins were known as chedunale. They were initiated in the profession through a ceremony known as Xens/Chens/Sensa. The girl was presented for the ceremony by an important person of the village. This man had the right to enter into a union with the girl after puberty.

The Xens cermony was like a marriage but with a difference. In this ceremony of initiation, the girl was married to an object, a flower usually a hibiscus or another girl dresses as a man. The Xens ceremony was also knows as atlaulim which means caressing or touching with hands. Widows of upper class including pregnant widows joined the profession when thrown out of their homes by their husband's family. Some women abandoned by their husbands also joined the profession. In: GRACIAS, F. S. The many faces of Sundorem: women in Goa. Panjim: Surya Publications, 2007. p. 17. 
Na obra de Osório de Castro a figura da bailadeira aparece com destaque não apenas no poema "Sâti" mas também em "Deva-Dassi", poema que integra As Flores de Coral. Nele o autor apresenta uma triste bailadeira, ainda menina, que quer morrer antes de envelhecer.

Com seu alvo sari de musselina

Vinha sempre na luz do fim do dia.

E a sua graça d'Oriental, tão fina,

E tão subtil, de amorosa e menina,

Era um filtro de oblívio e d'alegria.

Sempre sorrindo, às vezes, de tristeza

A doce voz velada, balbuciava:

- "Alma de bailadeiras, que estranheza!

Viver d'amor, e morrer de frieza!..." -

Risonha a boca, o olhar fundo sonhava.

O fruto ardente do seu colo abria

No escarlate corpete de cetim.

E que linda, e de sonho, parecia,

Entoando a milenária melodia,

A baloiçar-se em uma dança sem fim.

- "Quero morrer quando ainda for nova

E linda... Que frialdade, envelhecer!

Com o mogarim casaram-me ao nascer.

Hão de plantar-me um mogarim na cova,

Sempre bem verde, e sempre a eflorescer!..."

Mas logo como uma criança ria.

Ria e contava ditos, historietas, 
Antigos dramas que enlevada lia,

Sacuntala, mais linda do que o dia,

Bailadeiras amadas dos poetas.

Esparzia o esvoaçar da musselina

Um perfume de sândalo e jasmins.

Morre ainda linda, Apsarás pequenina!

Ah! dança e fulge como pedra fina!

Flor de ilusão, arde com teus rubins!90

Neste poema, escrito em 1907, são encontrados muitos elementos que permeiam toda a obra poética de Osório de Castro, tais como o cair da tarde, a morte e pedras preciosas.

A figura da bailadeira aqui retratada está bastante condizente com o que diz Gracias (2007), ainda menina foi casada com um mogarim, como é chamado o jasmim da Arábia no indo-português, planta bastante comum nos jardins de Díli. É interessante notar que Osório de Castro leva um elemento tipicamente timorês para a Índia, mantendo um vínculo com a realidade ao casar a bailadeira menina com uma flor, mas moldando seu Oriente ao fazer timorense a flor indiana. Também a veste com um elemento muito comum no vestuário das cortesãs ocidentais, o corpete de cetim, que fica por baixo do sari de musselina, a roupa usada pela maioria da população feminina indiana.

Por fim ele a compara a Sacuntala, a filha de uma Apsarás. As Apsarás eram, segundo glossário encontrado ao fim de As Flores de Coral

Divindades femininas, diz, de ordem secundária, cujo nome pela sua composição recorda o de Afrodite ( $A p$, água, sar, mover-se). Ninfas aquáticas na origem, transportadas pelas especulações dos Vedas, em companhia dos

90 CASTRO, A. O. Flores de Coral. In: Obra completa. Lisboa: Imprensa Nacional Casa da Moeda, 2004. p. 335-336. 
Gandarvas, seus esposos, para as águas místicas, cujas ondas são ora as nuvens ora as orações. [...] Podem chamar-se as bailadeiras celestes. ${ }^{91}$

Neste poema aparece ainda outro tema bastante recorrente na obra de Osório de Castro, a preocupação com a vida após a morte. Ao dizer que plantarão em sua cova um mogarim que continuará a florescer, ela mostra que tem o desejo de continuar viva na forma do jasmim, flor associada à vida, à beleza, ao casamento e também ao espírito na Indonésia.

Além das bailadeiras, nos templos havia ainda uma outra categoria de meninas que eram dedicadas a eles por seus pais quando ainda muito jovens, as bavinas. Elas realizavam diferentes tarefas tais como limpar os ídolos, limpar as lamparinas e mantêlas acesas durante os momentos de adoração, mas elas não dançavam no templo.

Além destas, há ainda outras temáticas que são frequentemente encontradas. Entre elas o amor e, principalmente, a morte, a implacabilidade do tempo, o fluir da vida, as saudades, sempre permeados por um quê de autobiográfico. Ana Maria da Conceição Oliveira chega a afirmar em sua dissertação Alberto Osório de Castro, ensaio bio-bibliográfico e crítico que o leitmotiv de toda sua obra seria, até certo ponto, a obsessão da morte. "É freqüente encontrar nos quatro volumes publicados este sentimento de vida que se esvai, como o fumo, do nada da vida humana". ${ }^{92}$

Ah! descansar enfim, ser alma simplesmente,

Na vaga névoa ir a subir levemente,

A subir! uma chama a subir e a findar. (CASTRO: 2004, 63)

Em carta escrita a Carlos Queirós é possível compreender melhor o conceito que o poeta faz da vida ao dizer que os vivos seriam nada além da continuação dos mortos, que nutrem de maneira misteriosa a vida. Na visão de Osório de Castro, tudo aquilo

91 Idem, p. 387

92 OLIVEIRA, A. M. C. Alberto Osório de Castro, ensaio bio-bibliográfico e crítico. Tese (Licenciatura em Filologia Românica) Faculdade de Letras, Universidade de Lisboa, Lisboa, 1959. 
que compõe a personalidade de alguém remonta aos antepassados e, a essa quase obsessão pela morte, soma-se uma outra, a da vida além-túmulo. No poema "Balada do dia de juízo", com epígrafe do Evangelho de São Lucas, na qual se lê "Ora Deus não o é de mortos, mas de vivos, porque todos vivem para ele" (cap. XX, v. 38), fica clara a preocupação com a questão da vida após a morte.

Passa o alvo luaceiro,

Passam os sóis num ardor,

Mailas chuvas, e nevoeiro...

Nada sentem, bom coveiro!

Nas Trevas estão, Senhor! (CASTRO: 2004, 75)

Junto desta temática há o gosto do poeta por assuntos mórbidos como a tuberculose e também a fragilidade, principalmente a feminina, como se observa no poema sem título de Exiladas:

Pálidas rosas a desfolhar,

ó Descendentes!

assim fraquinhas não podeis amar.

Ide sonhar na cova ao luar

bodas ardentes! (CASTRO: 2004, 82)

Dentro dessa obsessão que o poeta tem com a morte, o leitor se depara não apenas com a preocupação acerca da finitude da vida, mas também da figura da morte como 0 término de suas esperanças, alegrias e razões para manter-se vivo. Neste caso, o fim de elementos que o prendam à vida na Terra seriam os responsáveis pelo cessamento de sua existência no plano físico e, daí, sua preocupação com o que estaria por vir e Ihe aguardar na vida além-túmulo. No poema "De Profundis" é possível encontrar uma 
amostra de sentimento que tanto parece angustiar Osório de Castro.

Quase a dormir seguia vagamente

As espiras azuis do meu charuto,

Quando me ergui nervoso de repente,

Ouvindo ao longe uma toada dolente,

Um ritmo vago e trágico de luto.

Debruço-me à varanda alucinado

Para ver se na rua acaso passa

Algum enterro... Dorme o povoado

Num silêncio solene, entrecortado,

Do luaceiro à claridade baça.

- Pura nevrose, penso irresoluto... -

Oiço porém mais perto as litanias,

Sobe-me a escada a gelidez do luto!...

É dentro de mim, é dentro em mim que escuto

O funeral das minhas alegrias! (CASTRO: 2004, 83)

Como visto anteriormente, o movimento Simbolista, no qual o autor se insere, tem início a partir de uma firme oposição ao pensamento científico e faz com que seus poetas busquem uma religiosidade e um esoterismo como meios de contraposição.

Não se trata apenas do desencanto perante o quotidiano, perante a fealdade do interesse mundano e a bruteza de uma sociedade industrializada, mas sobretudo do desgosto íntimo face à opacidade de um universo material e mecânico, fechado em si mesmo, e da angústia mortífera do sem-sentido da Vida, a que iniludivelmente 
conduzira o pensamento positivista e cientista. ${ }^{93}$

Em vista disso, é notável que os temas de interesse que permeiam a maior parte da obra do poeta sejam relacionados à efemeridade da vida, à iminência da morte, à vida após a morte e também às saudades e ao amor, que são os sentimentos mais humanos quem podem existir e que estão presentes no poema "Sâti". Somado a isto está uma apreciação pelos aspectos mais orgânicos do mundo, seres e objetos que não dependem exclusivamente da tecnologia para que sejam apreciados, como mulheres bonitas, pedras preciosas e paisagens.

\subsection{Análise do poema "Sâti"}

Estando esclarecida a origem do nome do poema e alguns aspectos recorrentes da obra poética de Osório de Castro, condição fundamental para que um comentário maior possa ser feito a seu respeito, será feita uma análise nos moldes formais como propostos por Antonio Candido em O estudo analítico do poema.

Em seguida seremos levados a estudar o que o poema transmite, e o que tradicionalmente se chama o seu conteúdo, e neste caso nos aproximaremos de um estudo da poesia. Assim, chegaremos a ela partindo empiricamente das suas manifestações concretas, e não fazendo o caminho inverso, mais filosófico. ${ }^{94}$

Em primeiro lugar, como sugere Benno von Wiese e com a intenção de estudar o poema como estrutura, serão levados em consideração os aspectos levantados em "Fundamentos do poema", tais como discriminados na introdução do livro: sonoridade, ritmo, metro e verso. Assim será feito aquilo que Wiese chama de interpretação científica ou sistemática (wissenschaftlich), antes da interpretação

93 SEABRA, J. C. P. Decadentismo e Simbolismo na poesia portuguesa. Coimbra: Centro de Estudos Românicos. 1975. P. 61

${ }^{94}$ CANDIDO, A. O estudo analítico do poema. - São Paulo: Terceira Leitura, FFLCH - USP, 1993. p. 14 63 
pessoal e subjetiva.

Depois de expor a visão de von Wiese de como uma análise de poema deve ser feita, Candido sugere que faça-se um comentário antes de dar sequência à interpretação. É o que será feito a seguir.

Composto em Goa, em junho de 1906, mesmo ano em que foi publicado o livro em que está contido, "Sâti" difere de todos os outros poemas que estão em $A$ cinza dos mirtos, principalmente pela forma em que está escrito. Assemelha-se, visualmente, mais a uma peça de teatro do que a um poema, como se pode ver na cópia que se encontra anexa a este trabalho.

É dedicado a Fernando Leal, a quem Osório de Castro chama o mais poderoso poeta português que a Índia produziu. Apesar de nascido em Margão, Fernando Leal viveu quase sempre em Portugal e seguiu carreira militar. Foi muito amigo de Antero de Quental, conviveu no círculo de literatos portugueses, de quem era muito estimado por seus trabalhos como tradutor de poesia francesa e também pelas produções próprias. Camilo Castelo Branco the tece o que talvez seja o maior elogio que um ocidental possa fazer a um oriental quando diz que, apesar de indiano, "nada tem da poesia maviosa e florida das regiões do sol, e é todo ocidental na explosão realista."95 Como se constata, todos os preconceitos que na época havia entre Ocidente e Oriente são aqui agenciados. Como bem diz Said, "[...] a cultura européia ganhou força e identidade ao se contrastar com o Oriente, visto como uma espécie de eu substituto e até subterrâneo."96

Também é dedicado a Ardeshir Framji Khabardar, a quem Osório chama de fino Lirico do Guzerate, este menos conhecido do que Leal, escreveu New light on the Gâthâs of Holy Zarathushtra.

Cerca de dez anos antes da publicação de "Sâti", em 1894, é publicada em Portugal $O$ Pântano, a primeira peça de teatro simbolista, de autoria de D.

\footnotetext{
95 DEVI, V. e SEABRA, M. A literatura indo-portuguesa.Lisboa: Junta de Investigações do Ultramar, 1971. v. 1. p. 175.

96 SAID, E. W. Orientalismo. São Paulo: Companhia das Letras, 2007 p.30 
João da Câmara. Do mesmo ano data a publicação do primeiro poema dramático de Eugénio de Castro, Belkiss, cujas intencionalidades cênicas, como diz Duarte Ivo Cruz, o colocam em posição secundária. Com a publicação de O Rei Galaor, Eugénio de Castro coloca em situação difícil alguém que queira restringir sua análise exclusivamente ao teatro, pelo fato de a natureza da obra do poeta tornar difícil uma distinção entre textos dramáticos e textos não dramáticos. "Mas outro problema, muito mais delicado, se coloca - o da prórpia natureza teatral, cénica, dinâmica, dos textos que Eugénio de Castro rotula de 'dramáticos'."97

Há então que se pensar na diferença entre um poema dramático e uma peça de teatro. Apesar de ambos pertencerem ao gênero dramático, o primeiro não é escrito com a intenção de ser representado, ao passo que uma peça nasce com o propósito de ser trazida a público, não apenas em sua forma escrita mas também encenada. Duarte Ivo Cruz, a respeito da poesia dramática de Eugénio de Castro, diz que é difícil e chegaria a ser inclusive duvidosa, pois alguns de seus escritos poderiam ser experimentados no palco. Contudo, isso não garantiria a eles as "virtualidades de movimento e dinâmica essencialmente necessários à construção teatral, e que em boa verdade não preocuparam Eugénio de Castro."98

Outro expoente simbolista que se dedica ao teatro, com maior preocupação quanto à adequação de seus escritos ao palco do que Eugénio de Castro, é António Patrício. Talvez inspirado pelos escritos desses dois companheiros de Letras, Osório de Castro tenha se sentido inclinado a arriscar-se a escrever um texto dramático, um poema dramático.

Concretizando: sabe-se que o simbolismo polariza e torna relevante o verbo, a fala, a literatura teatral. E compreende-se que a palavra, em si mesma, implique certo grau de espetacularidade. Apenas isso, só por si, não conferirá à

97 CRUZ, D. I. Introdução à história do teatro português. Lisboa: Guimarães e Cia. Editores, 1983. p. 145.

98 CRUZ, D. I. Introdução à história do teatro português. Lisboa: Guimarães e companhia Editores, 1983. p. 145. 
obra um carácter cénico, se não for acompanhado de um mínimo de dinâmica teatral..$^{99}$

"Sâti" constitui a primeira experiência de Osório de Castro com a poesia dramática, pois até então o autor havia se dedicado apenas às estruturas poéticas mais formais. É possível notar um caráter cénico no poema, como na marcação das falas de cada um dos personagens que o compõe e nas rubricas que aparecem em itálico entre parênteses, mas estes elementos não são suficientes para fazerem do poema uma peça teatral. Apenas as rubricas são insuficientes para imprimir dinâmica de palco ao texto.

Composto por 390 versos, é sem dúvida o poema mais longo da obra. Quanto à métrica, Alberto Osório se vale de metros diferentes para sua composição; encontramos alexandrinos, hendecassílabos, decassílabos, octossílabos, rendondilha maior, hexassílabos, quadrissílabos e dissílabos. No que tange a forma do poema, não é possível encaixá-lo em nenhuma forma já nossa muito conhecida. Antes parece ter feito Osório de Castro uma combinação entre a literatura portuguesa, no que diz respeito ao uso de versos como a redondilha maior, quadri e dissílabos, e a literatura indiana clássica, védica, ao usar versos dodecassílabos, hendecassílabos, decassílabos e octossílabos.

No decorrer da pesquisa nos deparamos com um tratado sobre métrica védica clássica publicado em 1905 pela Universidade de Cambridge, na Inglaterra, e é sob a perspectiva nele apresentada que analisaremos a influência da forma oriental encontrada no poema "Sati". Foi escrito por um professor de latim da University College

99 Idem, p. 146. 
of North Wales, Edward Arnold, que usa o Rigveda, parte integrante da mais antiga coletânea de vedas ${ }^{100}$, para desenvolver sua tese.

Arnold começa por informar ao leitor que o Rigveda não se trata de um poema mas de uma biblioteca e uma literatura, compostas por vários poemas. Apesar da importância de seu conteúdo, sua forma não deve, de maneira alguma, ser desprezada e será ela uma de suas principais preocupações no decorrer de seu texto.

A literatura indiana clássica utiliza as seguintes unidades de metros em suas composições: verso, stanza e hymn. Um verso é composto por sílabas poéticas cujo número pode variar entre oito e doze, uma stanza é composta por um certo número de versos que geralmente pode variar entre quatro versos dimétricos de onze sílabas ou quatro versos trimétricos de doze sílabas; no entanto é possível que uma stanza seja composta por outros números de versos cujo número de sílabas também pode variar. Um hymn por sua vez é composto por um certo número de stanzas que normalmente consiste de não menos de três nem mais de quinze stanzas.

Temos então a menor unidade métrica da literatura védica, o verso, que é composto por sílabas poéticas da mesma maneira que na literatura ocidental clássica, a stanza, que é composta por conjuntos de versos da mesma maneira que a estrofe na literatura ocidental, e o hymn, que é composto por conjuntos de stanzas, não menos de três e nem mais de quinze.

$100 \mathrm{n}$. any of the four collections forming the earliest body of Indian scripture, consisting of the Rig Veda, Sama Veda, Yajur Veda and Atharva Veda, which codified the ideas and pratices of Vedic religion and laid down the basis of classical Hinduism. They were probably composed between 1500 and $700 \mathrm{BC}$, and contain hymns, philosphy, and guidance on ritual.

$<$ ORIGIN > Sanskrit, literally '(sacred) knowledge'.

SOANES, C. Oxford Dictionay of English, Oxford: Oxford University Press, 2010. Kindle Edition.

s.m. qualquer uma das quatro coletâneas que formam o mais antigo corpus das escrituras indianas, compostas pelo Rig Veda, Sama Veda, Yajur Veda e Atharva Veda, que codificam as idéias e práticas da religião védica e que estruturam as bases do hinduísmo clássico. Foram provavelmente compostos entre 1500 e 700 a.C. e contém os hinos, a filosofia e orientação sobre os rituais.

$<$ ORIGEM> Sânscrito, literalmente 'conhecimento (sagrado)'. 
Um verso é constituído frequentemente tanto por oito sílabas, quando o distinguimos como um dimétrico ou por onze ou doze silabas, ambas variedades sob o nome de verso trimétrico. ${ }^{101}$

O número de sílabas em um verso não é rigidamente prescrito. Portanto, muitos versos dimétricos contém apenas sete sílabas: tais versos, se eles correspondem em ritmo a um verso dimétrico comum com perda na última sílaba, nós chamamos de versos dimétricos cataléticos. De outra maneira, o termo mais geral heptassílabo também pode ser adotado.

Do mesmo modo, versos trimétricos que contém apenas dez sílabas não são incomuns, tais versos são geralmente equivalentes ao verso de onze sílabas com perda de uma sílaba antes ou depois da cesura. Estes versos mais curtos podem ser chamados de decassílabos. ${ }^{102}$

As formas mais comuns de stanza são:

(i) o Anustubh, que consiste em quatro versos dimétricos, e

(ii) o Tristubh, que consiste de quatro versos trimétricos de onze sílabas.

Quatro versos trimétricos, cada um de doze sílabas, formam uma stanza Jagatl. ${ }^{103}$

Stanzas podem conter mais ou menos versos do que quatro. Deste modo o Odyatri consiste de três versos dimétricos (sete ou oito sílabas poéticas), o Pankti de cinco e o Mahdpankti de seis sílabas poéticas: enquanto três versos Tristubh formam o metro conhecido por Virdj e dois decassílbados são conhecidos como

101 A verse consists most commonly either of eight syllables, when we distinguish it as a dimeter verse : or of eleven or twelve syllables, both of which varieties are included under the name trimeter verse. In: ARNOLD, E. V. Vedic Metre: in its historical development. Cambridge: University Press, 1905. p.7

${ }^{102}$ The number of syllables in a verse is not quite rigidly prescribed. Thus many dimeter verses contain seven syllables only: such verses, if they correspond in rhythm to an ordinary dimeter verse with loss of the last syllable, we term catalectic dimeter verses : if otherwise, the more general name heptasyllabic may be used.

Similarly, trimeter verses which contain only ten syllables are not uncommon, such verses being usually equivalent to the verse of eleven syllables with the loss of a syllable before or after the caesura. These shorter verses may be termed decasyllabic. In: : ARNOLD, E. V. Vedic Metre: in its historical development. - Cambridge: University Press, 1905. p.7

${ }^{103}$ The most typical forms of the stanza are:

(i) the Anustubh, which consists of four dimeter verses, and

(ii) the Tristubh, which consists of four trimeter verses, each of eleven syllables.

Four trimeter verses, each of twelve syllables, form a Jagatl stanza.

In: ARNOLD, E. V. Vedic Metre: in its historical development. Cambridge: University Press, 1905. p.7 


\section{Dvipadd Virdj."104}

Visto que o número de sílabas num verso não é rigidamente prescrito, temos que um verso dimétrico também pode ser composto por sete ou oito sílabas poéticas. Desse modo, uma stanza Anustubh pode ser composta por quatro versos dimétricos de sete ou oito sílabas poéticas. Do mesmo modo, uma stanza Tristubh pode ser composta por quatro versos trimétricos de dez ou onze sílabas poéticas.

Numa leitura minuciosa do poema em questão, "Sâti", em que a contagem de sílabas poéticas de cada verso seja feita, é possível perceber, como já dito anteriormente, que o poeta português faz uso de todos os tipos de versos clássicos védicos; tais como: dodecassílabo, decassílabo, octossílabo e heptassílabo. Assim, percebe-se que o poema em questão é composto por stanzas e hymns como se pode comprovar com o exemplo da primeira fala da Nagaína, uma stanza do tipo Tristubh:

"O seu marido juvenil e forte

Espera-o hoje Stiá Bay, Criança!

Há-de fazer-te enfim mulher, descansa.

Quem to assegura sou eu mesma: a Morte." (CASTRO; 2004, 247)

Ao fazer uso da métrica védica tradicional, Osório de Castro não deixa de lado suas referências ocidentais, antes parece querer combinar ambas ao escrever, por exemplo, versos deca e heptassílabos, comuns às duas. A inovação aparece na maneira em que as stanzas védicas são compostas, com um número maior de versos do que o comumente encontrado na tradição ocidental.

No caso da primeira fala do Bulbul (nome persa do rouxinol), em redondilha maior, temos duas stanzas de Mahdpankti, ou seja, duas stanzas de seis versos heptassílabos; como se pode ver:

104 "Stanzas may contain more or fewer verses than four. Thus the Odyatrl consists of three dimeter verses, the Pankti of five, the Mahdpankti of six : whilst three Tristubh verses form the metre known as Virdj, and two decasyllabic verses that known as Dvipadd Virdj. In: ARNOLD, E. V. Vedic Metre: in its historical development. Cambridge: University Press, 1905. p.8. 
"Ontem inda era menina,

E hoje, mulher, vai sofrer.

Não só amor, também dor

Faz da criança mulher.

Não sei se a dor ou o amor,

É a sorte da mulher." (CASTRO; 2004, 247)

A fala do Muruôni (um pequeno pássaro indiano, típico de Goa) é composta por três stanzas Anustubh, quatro versos em redondilha maior; como se pode ver:

"Não sei o que me adivinha

O coaração a parar.

Não parece descuidado,

Mas estar a soluçar."

Nos exemplos citados logo acima é possível verificar esta apropriação que faz Osório de Castro da métrica e forma oriental no uso das stanzas, que têm o número de versos característicos à métrica védica tradicional. Ao mesmo tempo usa a redondilha maior, tão comum na poesia ocidental.

A primeira fala de Sitá, não fosse um verso quadrissílabo a destoar, seria um perfeito exemplo de stanza Tristubh, composta por quatro versos decassílabos. Já a fala de um bando de gralhas é composta por versos quadri, hepta, hexa, octo e nonossílabos. A provável razão de não haver o mesmo número determinado de sílabas poéticas em toda stanza, se deve ao fato de o autor querer dar a impressão de ser mesmo um bando de pássaros em movimento, uma revoada desordenada, pois apesar de versos com o mesmo número de sílabas poéticas se repetirem, não há qualquer sequência na repetição, e com uma sonoridade aguda derivada da acentuação usada pelo poeta em palavras como "Sitá", "Káli", "Dêvi", "Viúva". 
Até agora falou-se da forma externa do poema, os diferentes metros e suas características mais óbvias, como o número de sílabas. Daremos agora importância à forma interna do poema, que consiste no ritmo dos diferentes tipos de verso. Segundo Arnold (1905), a forma interna é tratada com menos rigidez do que a externa na poesia indiana, pois no Rigveda - a coleção de versos sagrados védicos que Arnold usa como modelo para explicar a metrificação védica - não há nenhuma regra interna sobre o ritmo dos versos, pois cada verso é independente no que diz respeito à estrutura.

Analisando então esse outro aspecto material do poema, o ritmo, em Sâti, pela própria forma em que o poema está estruturado, se assemelhando mais a uma peça de teatro do que a um poema nos moldes em que o conhecemos, não há um ritmo constante. Ademais, se é a intenção do poeta era fazer uso da metrificação védica clássica, é natural que a estrutura rítmica do poema se mantenha como na literatura védica.

Cada personagem tem seu próprio ritmo e cadência que thes dão identidade. Como não há um metro fixo, a unidade rítmica do poema se caracteriza por sua descontinuidade. Assim como em uma narrativa - e este poema muito se assemelha a uma narrativa na medida em que tem inspiração no maior poema épico da literatura indiana, o Ramayana, como ficará mais claro adiante - a primeira figura que aparece é a do narrador, que vem nos apresentar o cenário no qual a história se desenrolará.

Sua fala está metrificada, principalmente, em versos decassílabos, havendo também alguns versos compostos por seis e quatro sílabas poéticas. Desta maneira não é possível classificá-lo em nenhum tipo de stanza como foi feito com os outros personagens que aparecem em sua sequência, como a Nagaína, o Bulbul e mesmo Sitá.

De acordo com o que vemos em Arnold (1905), entre os parágrafos 31 e 56, nos quais ele discorre a respeito do ritmo no Rigveda e, portanto, na literatura védica clássica de maneira geral, não há como comparar o processo rítmico védico ao português ocidental a que estamos acostumados. Primeiramente por não haver, 
mesmo na metrificação, uma rigidez como a que há na literatura portuguesa, como é o caso do versos trimétricos que podem ter onze ou dez sílabas se houver perda de uma sílaba antes ou depois da cesura. Não é possível determiar uma unidade rítimica, uma vez que os versos podem ter tamanhos distintos. No padrão ocidental, ou bem um verso tem dez ou tem onze sílabas poéticas e não são intercambiáveis; não se admitem sonetos em versos hendecassílabos, apenas decassílabos ou alexandrinos, ao passo que na literatura védica esse intercâmbio é possível caso haja perda de sílaba poética antes ou depois da cesura. Assim, se já é difícil definir uma unidade rítmica de cada personagem, cujo número de versos varia de acordo com cada aparição - como a Nagaína que tem stanzas do tipo Tristubh na primeira fala, um único verso de nove sílabas poéticas na segunda, um outro único decassílabo na quarta etc. não é possível definir uma unidade rítmica homogênea para todo o poema.

Ainda insistindo no tema do ritmo do poema e com ele no aspecto da sonoridade, não é possível deixar de notar um artifício que Alberto Osório usa para imprimir alguma sonoridade ao mesmo tempo em que introduz outra figura clássica indiana que desperta o interesse dos ocidentais, como já verificado anteriormente: a bailadeira. Primeiro, uma única bailadeira aparece cantando "no ritmo dorido e trémulo do saranghi e da murdanga ${ }^{105 "}$, para depois dar lugar a um coro de bailadeiras "numa coreia de evoluções mais rápidas"106. Esta parte aparece em forma de partitura musical com uma letra em língua estrangeira. Ao contrário da primeira bailadeira, que aparece cantando num ritmo aparentemente lento - por causa do adjetivo "dorido" -, o coro já é descrito como mais rápido e a indicação ao lado da partitura é de um andamento moderato, entre 108 e 120 batidas por minuto: "Depois, de novo o silêncio do calor e da luz cai". 107

\footnotetext{
$105 \mathrm{O}$ primeiro um instrumento de corda usado pelas bailadeiras ou pelos homens da mesma casta das bailadeiras e o segundo um tambor que acompanha as músicas hindus. In: CASTRO, A. O. Obra Completa, Lisboa: Imprensa Nacional Casa da Moeda, 2004. v. 1. p. 281 e 283

106 CASTRO, A. O. Obra Completa, Lisboa: Imprensa Nacional Casa da Moeda, 2004. v. 1. p.254

107 CASTRO, A. O. Obra Completa, Lisboa: Imprensa Nacional Casa da Moeda, 2004. v. 1. p.254 
A partitura que aparece na página 254 identificada como o coro das bailadeiras, reaparece na página 271 sob o título "Launim da canção da bailadeira a PP. 253-254" com a indicação da composição, atribuida a Djâiéçri Manekên Shirôdcârine e tradução para o português.

No glossário de termos indiáticos e indo-portugueses ao fim de A Cinza dos Mirtos encontramos a definição de launim

Launim - Toada das canções de bailadeiras, canção de amor. A canção muçulmana em hindustani, a p. 271 é um Râkâl ou Gâzâl.

A palavra launim do indo-português vem da mahrathi lávanim, derivada da palavra sânscrita comporta lavânhiamahi, próprio de beleza, gracioso. ${ }^{108}$

Deste modo, parece-nos que Osório de Castro não apenas foi leitor da literatura indiana clássica durante o tempo que esteve em Goa como também se apropriou dela e a incorporou em sua própria obra, no que diz respeito à metrificação, à sonoridade, ao ritmo e à escolha de tema e personagens.

O fato de a escolha do tema do poema recair sobre o sati, levaria um leitor desavisado a acreditar que Osório apenas chove no molhado ao escrever sobre um tema que já havia sido trabalhado por diversos outros europeus, como vimos. Contudo, é a abordagem que Osório de Castro faz do tema que joga sobre ele uma nova luz nada tradicional em relação à preocupação ocidental em tirar de cima da pira funerária de seus maridos a viúva indiana.

O poeta é original não apenas pelo uso da métrica védica tradicional combinada com a métrica utilizada pelos portugueses, que parece ser uma maneira de não se apropriar da literatura local e não apenas ocidentalizá-la no que diz respeito ao tratamento do tema e da configuração aos moldes considerados corretos de se escrever poemas, mas também pelo tratamento que dá ao tema de escolha.

108 CASTRO, A. O. Glossário de termos indiáticos e indo-portugueses. In: Lisboa: Imprensa Nacional Casa da Moeda, 2004. v.1 p. 279.

A Cinza dos Mirtos. 
Entre as muitas personagens que figuram no poema, a de Sitá é a principal. É ela quem irá morrer na pira funerária do marido morto. Sendo a erudição uma característica dos escritores simbolistas e sabendo que Alberto Osório de Castro tem conhecimento da literatura indiana clássica, como fica demonstrado na questão da métrica, é nítido que a escolha de Sitá para personagem principal não é aleatória. O poema clássico indiano Ramayana trata da história do príncipe Rama, filho de Dasaratha rei de Ayodhya, que é banido para a floresta por sua madrasta invejosa, a rainha Kaikeyi. Sabendo que Rama tomaria o lugar de seu filho Bharata na sucessão do trono de Ayodhya, Kaikeyi pede ao marido moribundo que envie Rama para a floresta por catorze anos, afim de que não suba ao trono, deixando livre o caminho para que seu irmão Bharata seja o novo governante de Ayodhya.

Rama é casado com a bela Sita, a quem desposou depois de conseguir envergar o arco de Shiva, objeto no qual consiste o dote da moça.

Sita era lindíssima. Tinha olhos escuros como os de uma corça, lábios carnudos, longos cabelos escuros que the caíam nas costas até os tornozelos, fragrantes por terem sido perfumados com fumaça de incenso. Trazia um sinal vermelho na testa e linhas de pasta vermelha e branca, de sândalo, nos braços; as solas dos pés tinham sido pintadas de vermelho com laca; ela envergava túnicas rubras e véus de prata, leves como o ar, cintos bordados e finas correntes que oscilavam quando ela andava, diademas cravejados de joias e tornozeleiras de sininhos, brotos de cevada atrás da orelha, grinaldas nupciais de jasmim e sete fieiras de pérolas à volta do pescoço, que lhe caíam sobre os seios, cheios e redondos. ${ }^{109}$

Esta descrição que encontramos no Ramayana é muito condizente com a descrição que encontramos no poema de Osório de Castro:

"Engrinaldada de champins e onlã,

109 BUCK, W. O Ramayana: O clássico poema épico indiano recontado em prosa por William Buck. Trad. Octavio Mendes Cajado São Paulo: Editora Cultrix, 2011. p. 94 
Vai já tomar o banho da manhã

Na verde fonte do arecal tremente

A doce Sitá Bay.

$[\ldots]$

Ó luz de alva serena e transparente,

Vede-a mirar naquela fonte fria

O corpo de âmbar, fino e adolescente."110

"Sitá (fazendo na fronte com o pó vermelho do cucume o sinal de bom agoiro, e derramando o óleo do sândalo na trança engrinaldada de flores)"111

Ou seja, apesar de no poema "Sâti" não haver qualquer referência a Rama como marido se Sitá, pela descrição da donzela é certo afirmar que se não for esta Sita a mesma do Ramayana, a da épica indiana serviu como modelo de inspiração para o poeta português.

Quanto às outras personagens que aparecem ao longo do poema dramatizado, há a Nagaína, conhecida no Ocidente como Naja e no poema também chamada de cobra-capelo. Na Índia também é conhecida por nagini ou naga, considerada como um espírito superior ao homem, são habitantes do paraísos subaquáticos e guardiões da energia vital e de riquezas das profundezas marinhas.

As princesas-serpentes, famosas por sua inteligência e encanto, figuram entre os ancestrais de muitas dinastias do sul da Índia: uma nagini ou um naga numa árvores genealógica confere à pessoa o suporte de uma nação. ${ }^{112}$

No "Glossário de termos indiáticos e indo-portugueses" presente ao final de $A$ cinza dos mirtos, ela é descrita como sendo a "verdadeira divindade hindu de Goa

\footnotetext{
${ }^{110}$ CASTRO, A. O. A Cinza dos Mirtos In: Moeda, 2004. v. 1. p. 246

. Obra Poética, Lisboa: Imprensa Nacional Casa da

111 Idem, p. 248.

112 ZIMMER, H. Mitos e símbolos na arte e civilização da Índia. São Paulo: Editora Palas Atena, 1989. p. 59. 
é a cobra-capelo, sob os nomes de Santéry e Shant-Durgá, ou Durgá, a Serena"113 . Venerada por toda Goa, é uma forma mais branda da deusa hindu Durgá e de acordo com informações encontradas no site de um dos templos da deusa, ${ }^{114}$ ela é considerada como a salvadora do hinduísmo em Goa.

Em todas as suas representações, Shanta-Durga aparece acompanhada por, pelo menos, duas serpentes. Em algumas está ladeada por elas enquanto que em outras aparece segurando-as, isso acontece em razão da briga que, a pedido de Brahma, apartou entre Shiva e Vishnu, que estariam representados na figura das cobras. Outra explicação para a presença das serpentes que vemos seguras nas mãos da deusa, é que elas seriam uma metáfora do bem e do mal, que ela constantemente coloca em cheque.
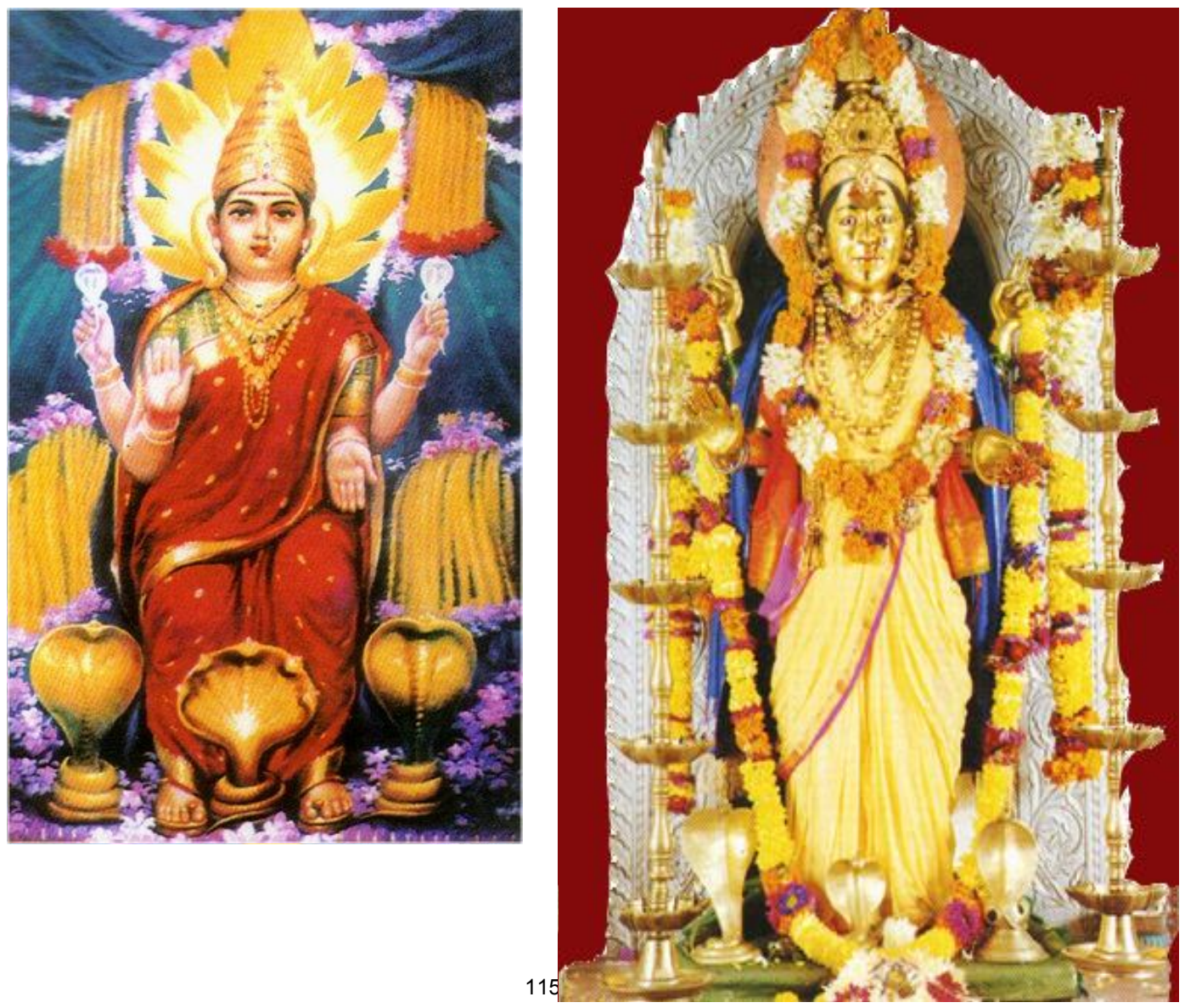

\footnotetext{
113 Idem, p. 281

114 Conferir: http://shantadurgakunkalikarin.org - site indiano da Deusa.

115 Ambas imagens retiradas de: http://www.shreeshantadurga.com/history_temple.asp 
É curioso notar que o nome da divindade hindu com o maior número de fiéis em Goa seja Shanta-Durga, nome que parece ter clara influência da palavra portuguesa "santa". Na religião católica este termo é usado para designar uma pessoa que foi formalmente reconhecida ou canonizada pela Igreja após a sua morte e que seja objeto de veneração ou preces para que interceda com Deus na obtenção de uma graça. Contudo, o Shanta tem origem palavra hindu "shanti", que quer dizer paz, e foi atribuído a ela quando a deusa pôs fim numa grande briga entre Shiva e Vishnu. Shanta quer dizer a pacificadora, significado não muito distante do português santa.

A mesma deusa é também popularmente conhecida como Saibini, nome de origem Konkani, uma das línguas oficiais de Goa, que confere uma designação de respeito. Ela representa a deusa mãe indiana e tinha alguns de seus santuários construídos sobre formigueiros, por ser uma divindade ligada à terra, além de templos dedicados a seu culto.

A existência de uma divindade com o nome Shanta-Durga em Goa parece ser uma forma de sincretismo religioso, no qual a religião hindu se apropria de elementos católicos para criar uma divindade própria da região. A chegada dos portugueses a Goa no século XVI trouxe na bagagem o cristianismo na forma da religião católica e com ela as conversões de nativos, feitas à força. Desse período de colonização portuguesa data a destruição de muitos dos templos dedicados ao culto de ShantaDurga, o que não impediu que ele continuasse na forma de Nossa Senhora e levou a Virgem Maria a ser chamada de Saibini. Em Pangim, a capital do estado de Goa, há uma igreja dedicada à Nossa Senhora da Imaculada Conceição. Em Salcete havia o maior templo dedicado a Shanta-Durga, no qual estava insatalada uma grande imagem da deusa que foi levada a Kavalem, em Pondá, onde está até hoje, quando os portugueses destruíram este santuário. 
Com o advento dos portugueses em Goa e o aumento das atividades missionárias, a comunidade temia pela segurança de seus templos e ídolos. Assim, as famílias devotas de Shanta-Durga e Magnesh, em uma noite sem lua, deixaram suas casas para trás e cruzaram o rio Juari (também conhecido como Aghashashini ou Agashi) carregando as imagens (murti) das divindades sobre suas cabeças e as transferiram para a região sob o governo do rei muçulmano Adilshaha. ${ }^{116}$

Em Goa, a daughter's story, encontramos mais informações sobre a adoração de Shanta-Durga na região.

Parvati, a consorte de Shiva, é amplamente venerada sob o nome de Shanta-Durga ou Santeri, bem como na igreja de Nossa Senhora dos Milagres em Mapuçá. Prasad, que vive na cidade, me explicou a ponte que há entre as diferenças religiosas na devoção da Deusa Mãe. Ela é a gramdevi de muitas das vilas e invocada por outros nomes também.

Uma proeminente manifestação de assimilação cultural é a transofrmação da deusa Santeri. O conceito de devoção da Deusa Mãe tem prevalecido em goa desde tempos pré-históricos como o culto de Saptamatrukas ou as sete irmãs ou as setes Deusas Mães. São elas Lairai, Saibin de Shirgao, Meerbai como Milagres de Mapuça, Morjai de Morjim, Mhalsai de Mardol, Mhamai de Mahem e Kelbai de Mugao, Adadeepa. E um solitário irmão, Khetoba.

Suas origens, de acordo com a lenda, datam da época pré-dravídica; ela era a Deusa Mãe e seu santuário o formigueiro. Mais tarde, sob influênais dravídicas e arianas que implementaram a construção de templos de madeira e

116 With the advent of the Portuguese in Goa and the increasing missionary activities, the community was afraid for the safety of the temples and idols. Hence the families worshipping Shree Shantadurga and Shree Mangesh, on a moonless night, leaving their homes and hearths behind crossed over the Juari river (also known as Aghashashini or Agashi river) with the images (murti) of the deities and the linga on their heads and shifted to the region under the rule of Muslim king Adilshaha. In: http:// www.shreeshantadurga.com/history_temple.asp 
pedra, quando os construtores se tornaram os marajás que liderou onda após onda de imigrantes, a maioria deles tomou a liberdade de dar a ela o nome de sua deusa (devi) preferida. Assim, ela foi rebatizada como Shanta-Durga, Vijaya Durga, Nava Durga mas todos são testemunhas apenas de Santeri Mai.

Contando com apenas dois santuários fora de Goa, é apenas em Goa que Santeri, em suas diferentes formas, é adorada, dando significado a seus atributos especiais como paz, fertilidade e proteção, os quais Goa tem orgulho de dar como sua contribuição à tradição indiana. Ela proporcionou a ponte entre as tradições hindu e católica em Goa e se transformou, tanto nela mesma como em sua irmã, Saibin Mai, a Virgem Maria dos cristãos.

A união de ambas tradições é ilustrada pelo ritual realizado para Saibin Milagres, a Rainha dos Milagres, na igreja católica de Mapuça, a capital do norte de Goa. [...] As duas comunidades se juntam na tradicional festa de Saibin Milagres, geralmente celebrada na terceira semana da páscoa. Tanto hindus como católicos formam grandes números de veneradores de Saibin e ofertam óleo e velas à deus. Fetsivais similares tanto de hindus como de católicos ocorrem em muitas vilas em Goa. A união da devoção apesar de fés separadas, é um fator que soma para a paz e harmonia em Goa e foi para esta tradição tão 
única que Shennoi Goembab apelou durante o estabelecimento da identidade goesa. ${ }^{117}$

Nossa Senhora da Medalha Milagrosa, também conhecida como Nossa Senhora dos Milagres, apareceu à jovem Catarina em julho 1830 na Rue du Bac em Paris. A jovem dormia quando foi acordada por um anjo que a conduziu até a capela onde Nossa Senhora lhe apareceu e prometeu que protegeria a comunidade do convento das desgraças da próxima revolução. Em novembro do mesmo ano Nossa Senhora reapareceu e pediu a Catarina que mandasse cunhar uma medalha para ser difundida. A jovem teve seu pedido negado quando contou ao padre confessor Gian Maria Aladel. Foi necessária uma terceira aparição da Virgem para que seu pedido fosse atendido e, em 1832, a medalha foi finalmente cunhada.

117 Parvati, Shiva's consort, is greatly venerated under the name Shanta Durga or Santeri as well as Out Lady of Milagres Church in Mapuça. Prasad who lives in the town explains to me the bridging of religious differences in worship of the Mother Goddess. She is the gramdevi of many a village and invoked by her other names as well.

A prominent manifestation of cultural assimilation is the transformation of the goddess Santeri. The concept of the worship of Mother Goddess has prevailed in Goa since prehistoric times as the cult of Saptamatrukas or the seven sisters or the seven mother goddesses. They are Lairai, Saibin of Si=hirgao, Meerbai as Milagres of Mapuça, Morjai of Morjim, Mhalsai of Mardol, Mhamai of Mahem and Kelbai of Mulgao, Adadeepa. And a lone Brother, Khetoba.

Her origins according to legend go back to pre-Dravidian times; she was the Earth Goddess and her shrine was the ant hill. Later with Dravidian and Aryan influences that brought in the building of temples in wood and stone, when the builders became har mahajans who led wave after wave of immigrants variously on record in rival Puranas, most of them took the liberty to install her under the name of their favorite devi. Thus she was renamed Shanta Durga, Vijaya Durga, Nava Durga, but all bear witness to only Santeri Mai.

Barring only two shrines outside Goa to goddess Santeri (and these are in the neighbouring state of Karnataka), it is only in Goa that Santeri in various transformations is worshipped, signifying her special attributes of peace, fertility and protection which Goa is proud to give as its special contribuition to the Indian tradition. She provided the bridge between the Hindu and Christian traditions in Goa. She became either in herself or in her sister, Saibin Mai, the Virgin Mary of the Christians.

The union of both the traditions is illustrated by the ritual performed for the Milagres Saibin, the Queen of Miracles, in the Catholic church at Mapuça, the capital of North Goa. [...] The two communities come together at the traditional feast of the Milagres Saibin, usually celebrated in the third week of Easter. Both Hindnus and Catholics assemble in large numbers to venerate the Saibin and offer oil and candles to her. Similar festivals of both Catholics and Hindus are held in churches for Santeri-Saibin in several villages in Goa. The union of worship despite separate faiths is a factor that accounts for communal peace and harmony in Goa; and it was to this unique tradition that Shennoi Goembab appealed to in the making of Goa's identity. In: COUTO, M. A. Goa: a daughter's story. Nova Delhi: Penguin Books, 2004. P. 206-207 


\begin{abstract}
A medalha traz de um lado a imagem da Virgem Maria de pé, com os braços abertos e raios saindo de suas mãos abertas. Os pés se apóiam num globo e estão esmagando uma serpente. A outra face traz um $M$ encimado por uma cruz e embaixo dois corações. Ao redor da medalha está escrita a jaculatória: "Ó MARIA, CONCEBIDA SEM PECADO, ROGAI POR NÓS QUE RECEBEMOS A VÓS."”118
\end{abstract}

É possível pensarmos então em uma equivalência entre Shanta-Durga, Nossa Senhora dos Milagres e Nossa Senhora da Imaculada Conceição, em cuja imagem constantemente aparece a figura de uma cobra. Ao contrário da divindidade indiana, tanto Nossa Senhora dos Milagres, quanto Nossa Senhora da Imaculada Conceição aparecem esmagando a cobra com o pé no que seria uma demonstração de sua pureza frente à corrupção da cobra que tentou Eva no Jardim do Éden, como se vê nas imagens a seguir.

118 ROMAN, E. N. Aparições de Nossa Senhora e suas mensagens e milagres. São Paulo: Paulus, 2012. p. 58 


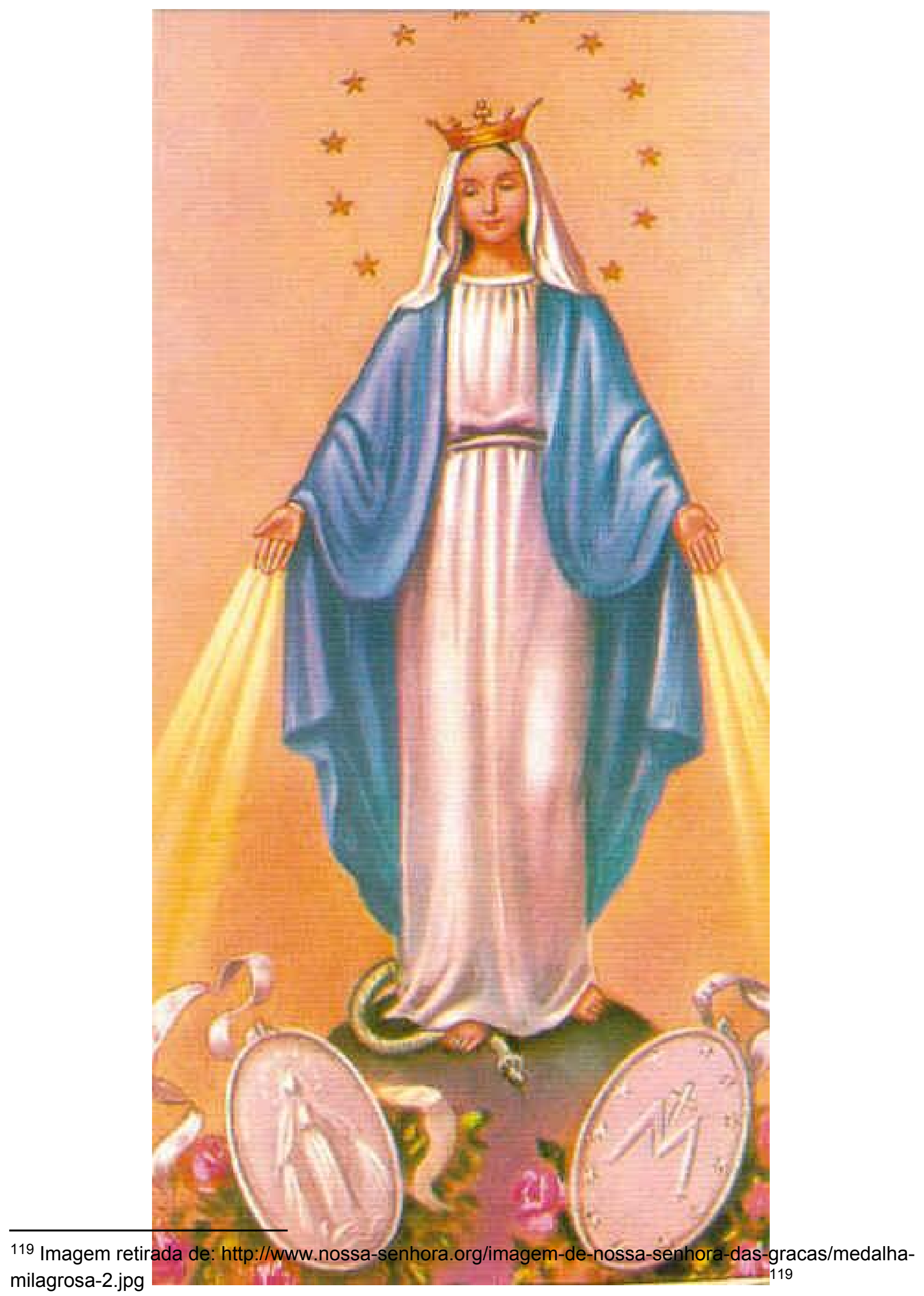




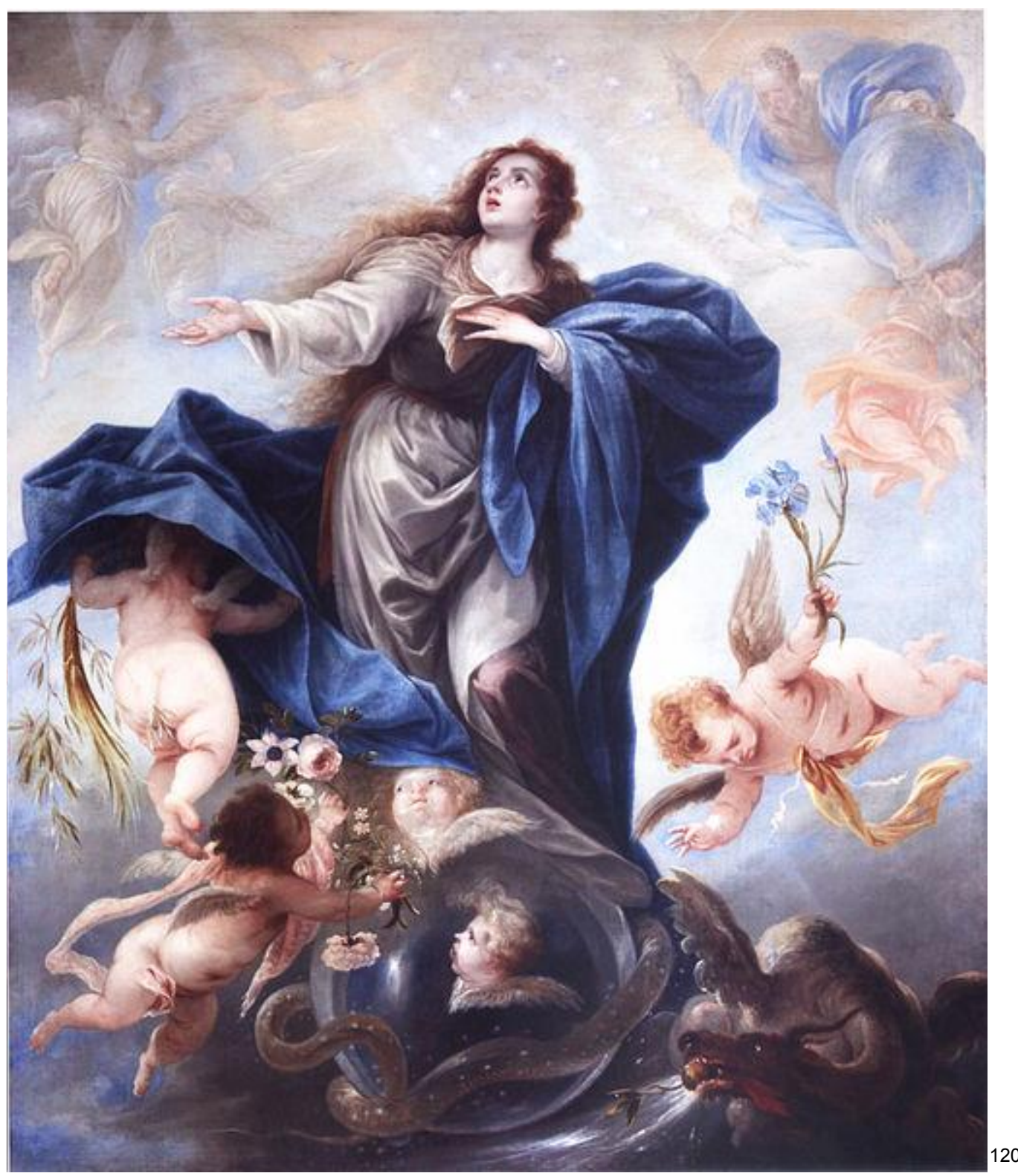

120 Inmaculada Concepcíon, óleo sobre tela, por Juan Antonio Frías y Escalante, cerca de 1667. Pertence ao Museum of Fine Arts of Córdoba. Fonte: Wikipedia, http://pt.wikipedia.org/wiki/ Imaculada_Conceição 


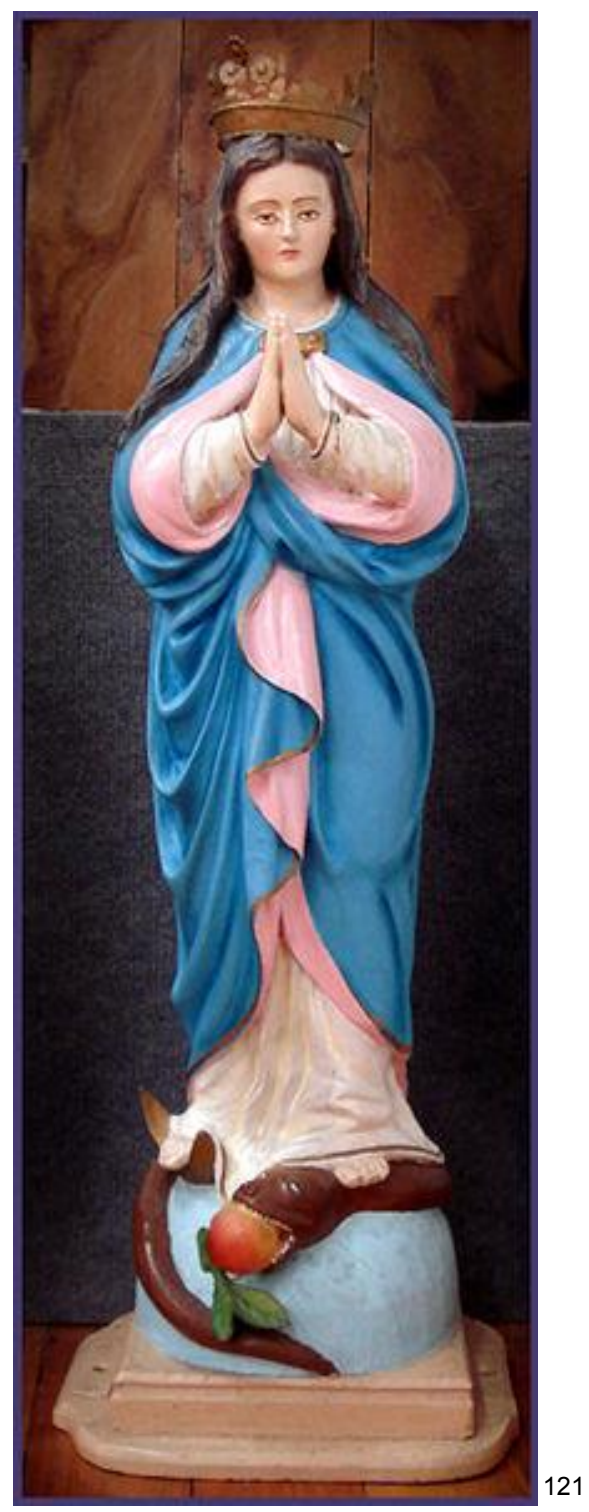

A religião católica prega que não apenas a concepção de Jesus Cristo tenha acontecido livre de pecado carnal, mas que também a concepção de sua mãe, Maria, tenha ocorrido da mesma forma. Para dar à luz o filho de Deus e desta maneira reconciliá-lo com o homem, seria necessário que a mulher que o concebesse e gerasse fosse totalmente livre de pecado, desde sua própria concepção.

121 Imagem integrante do acervo do Museu Municipal de Caxias do Sul, produzida no séc. XX pelo Atelier Zambelli. Fonte: Wikiepedia http://pt.wikipedia.org/wiki/lmaculada_Conceição 
Encontramos em Gênesis 3: 14-16 o momento em que Deus se revolta com Adão e Eva logo após terem cometido o pecado de comer do fruto da árvore do bem e do mal.

14 E o Senhor Deus disse à serpente:

"Porque fizeste isso, serás maldita entre todos os animais domésticos e entre todos os animais selvagens. Rastejarás sobre o ventre e comerás pó todos os dias da vida.

15 Porei inimizade entre ti e a mulher, entre a tua descendência e os descendentes dela. Eles te ferirão a cabeça e tu Ihes ferirás o calcanhar".

16 Para a mulher ele disse: "Multiplicarei os sofrimentos de sua gravidez."

A partir destes versículos é fácil compreender a razão de Nossa Senhora da Imaculada Conceição aparecer pisando sobre a cobra. Na condição de mãe do filho de Deus é sua responsabilidade fazer com que sua descendência esmague a da cobra e a elimine.

Enquanto que Shanta-Durga aparece na figura de mediadora de confilitos acompanhada por duas serpentes, que representam o bem e o mal, Nossa Senhora da Imaculada Conceição aparece representando o bem que esmaga o mal, na figura da serpente que tentou Eva e a levou a cometer o pecado original. Fazendo esta aproximação entre a deusa oriental indiana e a santa ocidental portuguesa, ambas entidades com grande número de devotos, é possível traçar um paralelo entre a Nagaína, a cobra capelo, que aparece no poema tentando Sitá com a serpente do jardim do Éden que fez Eva cair em tentação.

Ao longo do poema a Nagaína, que representa a morte, tenta fazer com que Sitá se encaminhe para a morte pois seu marido não está mais vivo.

\author{
O seu marido juvenil e forte \\ Espera-o hoje Sitá Bay. Criança!
}


Há-de fazer-te enfim mulher, descansa.

Quem to assegura sou eu mesma: a Morte. ${ }^{122}$

Tens a morte ao pé de ti:

Morre, pequena viuvinha! ${ }^{123}$

A cobra capelo consegue, enfim, convencer Sitá a deixar a vida, no que parece indicar que aqui houve uma vitória da serpente e não da deusa católica, como se espera que faça Nossa Senhora da Conceição. Ao fim do poema ela se encaminha para a selva que está em chamas após ser atingida por um raio.

Dois pássaros, o Bulbul (nome persa do rouxinol) e o Muruôni, um pequeno pássaro cantor da Índia, assim como o bando de gralhas, são aves que habitam o subcontinente indiano e, portanto, fazem parte da cultura local. A presença desses dois pássaros é bastante relevante ao poema por ser o Muruôni considerada uma ave símbolo de Goa, enquanto que o Bulbul (rouxinol) é o pássaro que no lirismo iraniano substitui o rouxinol dos poetas europeus. Desta maneira, ao trazê-los em separado e depois em coro, Osório de Castro aproxima elementos ocidentais e orientais no poema, assim como parece ter feito com as divindades.

Tanto o Bulbul quanto o Muruôni são aves que cantam ao fim do dia, durante o crepúsculo e assim vêm reforçar o tema do cair da tarde tão presente na obra poética de Osório de Castro. Sabemos que o poema tem início no cair da tarde por causa do canto dos pássaros e também por causa da rubrica encontrada após a última fala de Sitá, "toda floresta é um esbraseamento na noite"124.

Não sabemos qual a espécie do bando de gralhas que passa sobrevoando e cantando para Sitá, esse é um pássaro que conta com diferentes espécies, algumas que habitam o continente euroupeu e outras o asiático. Não foi possível encontrar

122 CASTRO, A. O. A Cinza dos Mirtos. In: Obra Poética. Lisboa: Imprensa Nacional Casa da Moeda, 2004. v. 1. p. 247

123 Idem. p. 249

124 Idem, p. 263 
qualquer referência a este pássaro na mitologia indiana, ficamos então com a impressão de que seja uma maneira que Osório de Castro encontrou de inserir um elemento ocidental no poema. A gralha é o aspecto noturno do corvo, o que vem reforçar a idéia do cair da tarde e início da noite no poema.

Há quatro coros diferentes que dialogam com Sitá: o coro dos homens novos, que incitam-na a tornar-se uma sati ao dizerem:

"A mulher só é grande se acompanha

Na morte o seu amor.

Se não morrer, Sitá! teu coração

É a flor de surâne, amarga e estranha,

Que é como luto e podridão.

Morre, Sitá! se te fez grande a dor."125

Já o coro dos anciãos, que, por serem mais velhos, costumam ser mais apegados às tradições locais, e parece justamente questionar a validade do rito e o ato de se matar na fogueira quando propõe a seguinte pergunta: "Há-de um corpo de amor cinzas ficar?"126

O coro das mulheres, que traz para Sitá todas as suas jóias, seu sari de noivado e a adornam, são a favor da morte e tentam convencer Sitá a imolar-se, mas de maneira mais sutil do que o coro dos homens novos.

"Ai! morrejá, pobre amor!

Antes em cinzas ficar

Do que viveres na dor,

Que seres viúva e durar"127

125 Idem, p. 250

126 Idem, p. 251.

127 Idem, p. 251 
Ao contrário do que foi visto em Gracias (2007), Sitá imola-se na pira ainda vestida e adornada com suas jóias, além da grinalda de flores que traz na cabeça.

Quanto ao que diz o coro das bailadeiras, pouco é possível saber, pois não há sequer uma indicação de qual é a língua em que elas cantam. Contudo, por ser em um ritmo com certa velocidade como é o caso do Moderato (108 a 120 batidas por minuto) e pela indicação de que estão "numa coreia de evoluções mais rápidas"128, é possível imaginar que elas incitem Sitá a fugir da floresta e da fogueira enquanto há tempo. Pode-se chegar a essa conclusão a partir do que antes do coro fala Djâiéçri, a bailadeira que fala sozinha, quando diz:

"O amor é instante apenas.

$E$ as almas enfim serenas

Vão cada qual seu caminho.

O desejo é sonho breve,

Desfaz-se num fogo leve.

Vem! Embriaga um carinho."129

Ela parece dar a entender que, apesar de belo, o amor é passageiro, dura um instante apenas e depois de findo as almas devem cada qual seguir seu caminho. Ora, se amou-se um homem que agora está morto, não há razão para querer manter-se em sua lealdade, morrendo em sua pira funerária, uma vez que, depois de passado o instante do amor, que é embriaguez ligeira, tudo se vai.

Falam com Sitá espécies da flora local como o bambual sem folhas, as vozes na floresta de teca e de sadrás (espécies de madeira locais), as raízes das avencas e dasselaginelas, bem como o coro dos outeiros e do jangal (um aportuguesamento de jungle, selva), as vozes da terra e os lótus vermelhos e brancos.

As vozes da floresta de tecas e de sadras não falam diretamente com Sitá, mas para quem quiser ouvir. Elas reclamam do que o destino reserva a elas: a 
transformação em combustível para a pira funerária que em breve será acesa. Pouco depois é a vez de ouvirmos as vozes do bambual sem folhas, que assim como as vozes anteriores não se dirigem diretamente a Sitá, mas a quem puder ouvi-las, e falam sobre o estado miserável em que se encontram. Passam frio, não têm mais uma única folha em seus galhos e são ignorados por quem por elas passa. Nas paredes as raízes das avencas reclamam de sede, da falta de água, assim como as raízes das selaginelas, que falam sobre a relva morta por falta d'água..

O coro dos outeiros e do jangal se dirige em agradecimenteo a Sûrya, o divino sol resplandecente que tem compaixão com a terra ardente e vai ao céu de Indra em busca da lua para dar uma trégua ao calor que seca e mata toda a flora local. As vozes da terra imaginam como seria ficar eternamente absortas neste sonho noturno, durante o qual nada é fecundado.

Por fim temos as falas dos lótus vermelhos e brancos, que parecem vozes suaves ao falarem em coisas doces como a carícia do luar e amantes que vêm buscar a paz das águas. Esta flor, que desabrocha sobre águas geralmente estagnadas e turvas"130, é um dos símbolos mais tradicionais da mitologia indiana, simbolizando o crescimento espiritual e a entrada para o útero do universo.

Abre-se para dar à luz, primeiramente, a Brahma, o criador demiúrgico. De seu percicarpo brotam as hostes do mundo criado. De acordo com a concepção hindu, as águas são feminias; são o aspecto procirador e maternal do Absoluto e o lótus cósmico é seu órgão gerador. [...] Ela é personificada como Deusa-Mãe, através da qual o Absoluto ingressa na criação. ${ }^{131}$

\footnotetext{
130 CHEVALIER, J. e GHEERBRANT, A. Dicionário de símbolos, mitos sonhos, costumes, gestos, formas, figuras, cores, números. Rio de Janeiro: José Olympio, 2009. p. 558

131 ZIMMER, H. Mitos e símbolos na arte e civilização da Índia. São Paulo: Editora Palas Atena, 1989. p. 77
} 
Elas falam sobre o desabrochar dos sonhos que amantes depositam no fundo de suas águas, em oposição aos sonhos de amor que Sitá quer enterrar no fogo ao entrar na fogueira.

Funcionando como o coro da tragédia, as plantas falam de forma geral sobre a miséria humana e o destino trágico reservado a Sitá, assim como sugerem a transcendência e a superação, associadas à morte.

Aparecem ainda o tigre real, o Mahatmã (a figura de um asceta, de um iogue) e o Bôtho (um sacerdote hindu), que representam elementos típicos do subcontinente indiano e a pequena sombra branca eurasiana e a sombra de bárbara escrava. Percebe-se, então, que têm como característica comum a distinção social: o tigre representa a fúria da Devi, a "materialização do aspecto destrutivo da Mãe do Mundo"132, uma figura com ligação direta com o divino e a figura do asceta é uma das mais reverenciadas e um sacerdote hindu é parte integrante da casta mais alta do sistema, os brâmanes. Parece ser uma forma de afirmar o valor da cultura milenar indiana, suas tradições, seu peso histórico, em contradição, aos olhos ocidentais, com o costume do sati.

As falas do Mahatmã parecem tentar fazer Sitá questionar o ato de imolarse, especialmente quando questiona se ela sabe o que é de fato o amor, se já amou. Ao mesmo tempo a Nagaína incita Sitá a tornar-se sati e acaba por conseguir o que quer, assim como a serpente conseguiu fazer com que Eva provasse do fruto do conhecimento da árvores do bem e do mal no Jardim do Éden. Ao final do poema Sitá entra no incêndio e morre queimada, dando continuidade ao antigo rito que tanto instigou a curiosidade e imaginação dos escritores e leitores ocidentais.

Vemos, portanto, que o poema sintetiza os temas que foram identificados anteriormente na obra poética de Osório de Castro. Apesar de o poeta trazer o Oriente para sua poesia e revelar conhecimento profundo de alguns aspectos da mitologia indiana e de como ela de mesclou com a religiosidade portuguesa, como no caso de Shanta-Durga e Nossa Senhora dos Milagres/Nossa Senhora da Conceição, além de

132 Idem, p. 153 
conhecimentos acerca da métrica védica clássica, os temas que aborda no poema não fogem a um espectro de interesses que o poeta sempre revela: a morte, o crepúsculo, o amor, recorrentes no simbolismo português. 


\section{Considerações finais}

A partir desse quadro em que observamos o conjunto do poema e dentro dele as personagens, a métrica utilizada que é baseada na métrica védica tradicional e, acima de tudo, a abordagem que Alberto Osório de Castro dispensa ao tema de sua escolha, podemos então concluir o que pretende este estudo: responder qual o tratamento que 0 poeta dispensa ao Oriente em sua obra.

Diz Edward Said que "os homens sempre dividiram o mundo em regiões que

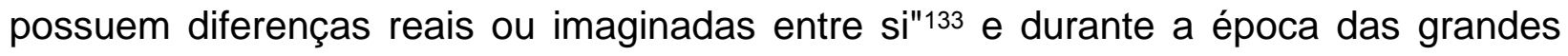
navegações e da expansão do império marítimo português, muitas destas divisões deixam de ser imaginárias e se tornam concretas também do ponto de vista geográfico. A partir do momento em que os portugueses se estabelecem em Goa, a figura do outro como imaginação deixa de existir para dar lugar a um outro que é agora real, com diferenças que podem ser ou não as que havia criado a imaginação dos portugueses a respeito de quem seriam os locais. Contudo, antes mesmo de chegarem à Índia e de fato terem contato com os orientais, já havia a noção pré-estabelecida de que

Há ocidentais, e há orientais. Os primeiros dominam; os últimos devem ser dominados, o que geralmente significa ter suas terras ocupadas, seus assuntos internos rigidamente controlados, seu sangue e seu tesouro colocados à disposição de uma e de outra potência ocidental. ${ }^{134}$

Portanto, estes portugueses já sabem o que deve ser feito, uma vez que tenham chegado no sub-continente indiano. E é sob a ótima de Homi Bhabha de que "o que precisa ser questionado, entretanto, é o modo de representação da alteridade ${ }^{\prime \prime 35}$ que

133 SAID, Edward W. Orientalismo: O Oriente como invenção do Ocidente. - São Paulo: Companhia das Letras, 2007. P. 72.

134 Idem. P. 68.

135 BHABHA, Homi K. O local da cultura. - Belo Horizonte: Ed. UFMG, 2010. P.107. 
podemos entender o olhar e o tratamento que Alberto Osório de Castro dispensa a esta questão em sua obra poética.

Como vimos, o próprio Osório de Castro revela ter consciência de sua perspetiva ocidental, quando de sua visita ao museu pessoal que o amigo e também orientalista Camilo Pessanha em Macau. Nesse episídio, é curioso lembrar o conhecimento que Osório de Castro revela ter acerca da arte oriental que lá encontra. Ele é capaz de identificar, por exemplo, tipos diferentes de pintura: "esse segundo painel (um ló-on), que se me afigura de maior valor artístico". ${ }^{136}$ Camilo Pessanha, apesar de ser um curador apaixonado por seu museu, questiona o tipo de arte produzida pelos orientais e pelo mesmo caminho envereda Osório de Castro quando fala sobre a arte chinesa.

[...] a raça chinesa é, pelo menos em relação a algumas das qualidades cujo complexo constitui o senso estético e a aptidão artística, melhor dotada que a raça européia; e mesmo a vida chinesa é mais dotada de arte que a nossa. E contudo não existe artista chinês que mereça confronto com qualquer dos nossos artistas de gênio, nem obra de arte chinesa que mereça ser catalogada como obra-prima. Não obstante seus grandes dotes naturais os Chins não conseguiram elevar o espírito até à noção de arte pura, ou arte filosófica; a arte deles é apenas decorativa, ou de aplicação. ${ }^{137}$

Osório de Castro não se conforma com o fato de, na China, não se tratarem nas obras de arte de temas como o trágico, o patético e o nu, tão presentes na arte e na literatura ocidentais.

Desde que a arte chinesa não é filosófica, mas apenas decorativa, disseme Camilo, o único efeito procurado pelos artistas é o pitoresco; e esse obtém-

\footnotetext{
136 CASTRO, A. O. Camilo Pessanha em Macau. In: LANCASTRE, Maria José de. Camilo Pessanha, cartas a Alberto Osório de Castro, João Baptista de Castro e Ana de Castro Osório. - Lisboa: Imprensa Nacional Casa da Moeda, 1984. p. 125

137 Idem, p. 126 
se mais facilmente com tratarem-se outros assuntos menos elevados, e que demandam menor estudo. ${ }^{138}$

Osório de Castro e Pessanha observam a arte chinesa do ponto de vista ocidental, que é o mesmo que usam para criticá-la quando dizem que, para os chineses, a arte não é senão um meio de tornar a vida mais agradável.

O risonho epicurismo egoísta de que está saturada toda a vida social chinesa, é incompatível com a noção da beleza trágica; à cultura do nu opõemse os ritos, os costumes, a civilidade da raça. Mas com todas as suas limitações, que deliciosa coisa não é toda essa arte chinesa, que enchia de riso, de luz, de colorido, de flores a doce tebaída macaísta de Camilo!139

Com essa fala, percebemos que Osório de Castro considera a arte chinesa um objeto de curioso interesse, ao qual se deve dedicar atenção caso o observador queira ter prazer naquilo que vê, mas que não serve como objeto de estudo mais profundo uma vez que não aborda assuntos relevantes aos ocidentais como a morte e o trágico. Na visão ocidental que faz Osório de Castro sobre a arte chinesa temos que ela é apenas decorativa, tendo como única missão tornar a vida de seu observador agradável. Trata-se, portanto, de uma relação com a arte dos países asiáticos que está calcada, em primeira instância, na idéia de superioridade da arte européia, o que, em última instância, se fundamenta numa relação de poder. Sobre o aparato de poder diz Bhabha (2010)

É um aparato que se apóia no reconhecimento e repúdio de diferenças raciais/culturais/históricas. Sua função estratégica predominante é a criação de um espaço para "povos sujeitos" através da produção de conhecimentos em termos dos quais se exerce vigilância e se estimula uma forma complexa

\footnotetext{
138 Idem, p. 127

139 Idem, p. 127
} 
de prazer/desprazer. Ele busca legitimação para suas estratégias através da produção de conhecimentos do colonizador e do colonizado que são estereotipados mas avaliados antiteticamente. O objetivo do discurso colonial é apresentar o colonizado como uma população de tipos degenerados com base na origem racial de modo a justificar a conquista e estabelecer sistemas de administração e instrução. [...] Portanto, apesar do "jogo" no sistema colonial que é crucial para seu exercício de poder, o discurso colonial produz o colonizado como uma realidade social que é ao mesmo tempo um "outro" e ainda assim inteiramente apreensível e visível. ${ }^{140}$

Portanto, no que diz respeito às relações de poder, evidencia-se que o poeta português olha para o Oriente, de maneira geral, com olhos de ocidental está mais do que claro, colocando-o na posição de colonizador que ele exerce durante os anos em que ocupa o posto de magistrado em Goa verificamos melhor como ele usa o "discuro colonial como aparato de poder"141.

No que tange o tratamento que Osório de Castro dispensa ao Oriente em sua obra poética, nos preocupamos, ao longo deste trabalho, em verificar como se insere a Índia, mais precisamente a região de Goa, neste quadro. As principais figuras que vimos ser abordadas por ele em seus poemas foram as femininas, na forma da bailadeira e da sati, temas explorados por outros autores ocidentais ao abordarem 0 Oriente em suas obras.

Ao abordar temas que já haviam sido tratados na literatura ocidental, Osório de Castro traz para seu leitor algo que dele pode não ser completamente desconhecido mas ainda assim exótico o suficiente para Ihe chamar atenção e despertar curiosidade. Da sua posição de magistrado, alto funcionário da metrópole que ainda mantém Goa sob seu domínio depois de cerca de 300 anos de colonização, tem poder real e simbólico suficiente para julgar e apresentar os colonizados como melhor lhe convém.

\footnotetext{
140 Idem, p. 111

${ }^{141}$ BHABHA, H. O local da cultura. Belo Horizonte: Ed. UFMG, 2010 p. 111 
Tocar num tema que mexe tão profundamente com o imaginário ocidental como o sati, costume considerado bárbaro, é justificar e legitimar sua posição de colonizador sobre aquele povo à época em que "Sâti" foi escrito. No entanto, ao introduzir no poema personagens que tentam demover Sitá de sua intenção de imolar-se, como o coro dos anciãos, procura amenizar o olhar estigmatizador, por um lado, e trazer valores ocidentais ao poema, por outro, tornando-o mais palatável para seu público ocidental, que pode respirar aliviado ao perceber que há na Índia quem seja nativo e contra tão bárbaro rito.

No tocante à bailadeira, não fosse o fato de serem elas associadas a um templo religioso, seriam bastante parecidas com a figura da cortesã européia. É necessário, claro, fazer ressalvas no que diz respeito à idade com que as meninas eram dedicadas ao tempo que serviam, ao fato de serem casadas simbolicamente com uma flor ou mesmo outra menina vestida de homem e no rito de iniciação que tinham à profissão. Tudo isso confere ao leitor ocidental um sabor de exotismo a uma figura que pode se aproximar de algo que já resida em seu imaginário, como uma cortesã.

Um aspecto bastante positivo da obra de Osório de Castro é a utilização que faz da métrica védica, como pudemos observar na análise do poema "Sâti". O poeta buscar ir mais a fundo do que outros no conhecimento acerca da literatura e cultura indianas ao incorporar elementos da métrica védica clássica em suas composições poéticas.

É impossível pensar que em uma relação entre povos colonizados e colonizadores apenas um dos lados seja modificado; apesar disso, costumamos pensar que somente os povos colonizados sofrem influência daqueles por quem são dominados. Todo o movimento simbolista e a Europa, de algum modo, se modificaram no contato com as formas artísticas asiáticas no século XIX, ainda que a força de tal modificação seja difícil de mensurar culturalmente.

Bhabha (2010) fala sobre a ambigüidade que existe no discurso colonial, pois na medida em que o colonizador se vale de "efeitos literários miméticos, a mímica emerge 
como uma das estratégias mais ardilosas e eficazes do poder e do saber coloniais. ${ }^{142 "}$ Nessa mímica surge "o desejo de um Outro reformado, reconhecível como sujeito de uma diferença que é quase a mesma, mas não exatamente. ${ }^{143 "}$

No que concerne à relação de Osório de Castro com a literatura portuguesa, sistema literário do qual sua obra faz parte, vale lembrar que o seu orientalismo angariava-Ihe certo prestígio peculiar, isto é, atribuía-lhe no meio literário um diferenciado capital simbólico, como concebido por Pierre Bourdieu (2011), permitindoIhe ser acetio pelos "critérios que definem o exercício legítimo de um tipo determinado de prática intelectual ou artística"144. Sua peculiaridade se dava no âmbito da relação entre arte e experiênca. Vivendo na Ásia e tomando temas asiáticos para sua poesia, blindava qualquer questionamento sobre a originalidade de seu trabalho, tendo por pressuposto que resultava de sua experiência concreta de mundo, o que vimos não ser toda a verdade.

Ao abordar o Oriente em sua obra, Osório de Castro, por ter estado lá e vivido a Índia, mostra ter domínio sobre o assunto que trata e sobre a arte que produz 0 que the dá legitimidade para criticar seus pares. Ele se torna integrante da categoria dos produtores de erudição e de critérios de avaliação. Há, entre os produtores de erudição, uma relação objetiva com as diferentes instâncias de legitimação, que consistem em instituições específicas, capazes de consagrar por suas sanções simbólicas e, em especial, pela cooptação, um gênero de obras e um tipo de homem cultivado. Osório de Castro, ao produzir conteúdo sobre o Oriente tendo tido essa vivencia in loco, se insere na categoria de homens produtores dessa erudição.

Quer referendando a poder colonial, quer compartilhando da ambigüidade de seu discurso, é inegável que a obra de Osório de Castro inventa um Oriente erudito e fundado em profunda reflexão e detido estudo, que faz com que possamos voltar a ela várias vezes e encontrar novas e novas chaves de leitura. A nossa se fecha aqui.

\footnotetext{
142 BHABHA, H. O local da cultura. Belo Horizonte: Ed. UFMG, 2010 p.130

143 Idem, ibidem.

144 Idem, p. 108. 
Ao mais poderoso Poeta oprtuguês

que a Índia produziu, a Fernando Leal;

e ao fino Lírico do Guzerate,

Ardeshir Framji Khabardar

Aves, cantai! Fullas desabrochai

$\mathrm{Na}$ alfombra viridente

Engrinaldada de champins e onlã,

Vai já tomar o banho da manhã

Na verdade fonte do arecal tremente

A doce Sitá Bay.

Aves do outeiro, flor do tamarindo,

Festejai o seu corpo esvelto e lindo.

Aves, cantai! Fullas desabrochai!

Ó luz de alva serena e transparente,

Vede-a mirar naquela fonte fria

O corpo de âmbar, fino e adolescente.

Ela não sabe o que lhe traz o dia!

Flores que a minha vista adora, Indianas flores, 
Sangue da ixora!
Ó quisquális de aromas e rubores!

De Sitá, vossa irmã.

Dizei a história entrecortada de ais,

Flores que a minha vista adora,

Indianas flores,

Sangue da ixora!

Ó ogarins, doirada surungã

Doces zaiôs que os mortos perfumais!

A NAGAÍNA (silvando num ramo de pandanuns em flor)

O seu marido juvenil e forte

Espera-o hoje, Sitá Bay. Criança!

Há-de fazer-te enfim mulher, descansa.

Quem to assegura sou eu mesma: a Morte.

O BULBUL (voando, num último canto:)

Ontem inda era menina,

E hoje, mulher, vai sofrer,

Não só amor, também dor

Faz da criança mulher.

Não sei se a dor ou o amor,

É a sorte da mulher

Sou a doçura da noite.

E quem a mim me procura 
Traz no coração o luar,

Ou não sabe o que é ventura.

Como é bom chorar, chorar,

Soinho na noite escura.

O MURUÔNI (sobre as mangueiras pendidas de frutos)

Não sei o que me adivinha

O coração a parar.

Não parece descuidado,

Mas estar a soluçar.

A gente às vezes pressente

A má notícia chegar,

E quantas vezes se canta

Só com medo de chorar.

Ó dia que estás nascendo

Com a estrela alva a brilhar,

Ai! Não lembres a quem chora

Que a noite the vai tardar!

SITÁ (fazendo lentamente na fronte com o pó vermelho do cucume o sinal de bom agoiro, e derramando o óleo do sândalo na trança engrinaldada de flores:)

Tomo por testemunhas, meu amado!

Do juramento que vos dei, sagrado,

O fogo a terra, a lua, o céu, e o mar, E o sol doirado:

Onde estiverdes vós eu hei-de estar. 
UM BANDO DE GRALHAS (voando da direira para a esquerda do caminho:)

Corre, Sitá!

O teu marido visitou Cassi,

Mas morreu já.

Assim o quis Káli! Káli!

Quem foge aos olhos da Dêvi?

Tu és viúva, Sitá,

És a arqueira sem chuva.

Viu’va! Viúva! Viúva!

(Sitá, soltando um grito, foge espavorida para a casa de família, ao longe, entre os palmares)

O BULBUL:

Vai, pequenina Virgem perfumada

A sândalo e a jasmim.

Eras o amor, e não serás amada.

A NAGAÍNA (silvando:)

Por que há-de amar-se se o amor tem fim?

MURUÔNI:

Não sabias predê-lo nos teus braços,

Adormecê-lo aos beijos!

Ignoravas que os beijos e os abraços

Enleiam de desejos.

A NAGAÍNA: 
Quem se desprenda, ó Maia, dos teus laços!

O BULBUL:

Pobre Sitá, coitadinha!

A flor do parisathi

Abre e cai triste à noitinha.

Cai, toda triste, viuvinha.

Quem terá pena de ti!

A NAGAÍNA:

Tens a morte ao pé d eti:

Morre, pequena viuvinha!

( $A$ casa de família é cheia de dor e prantos.)

CORO DOS HOMENS NOVOS (à entrada:)

Entre arecais e fecundas palmeiras

Ela passou, a filha da desgraça.

Gritai, abutres! aves agoureiras!

A maldição da Raça.

A mulher só é grande se acompanha

Na morte o seu amor.

Se ão morres, Sitá! teu coração

É a flor de surâne, amarga e estranha,

Que é como luto e podridão.

Morre, Sitá! se te fez grande a dor.

Filhas da Índia, ó flores de peçonha

E de ilusão, 
EM cujo seio uma serpente sonha

O veneno e a traição,

Almas de dor e graça!

Não vos entendem nossas almas, não.

Essa doçura de planta magoada

É a datura suave e perfumada

Qque nos esconde a vossa agitação.

Trazeis do banho os lótus das lagoas.

E nas noites de pálida safira,

Corpo em flor da mulher, como atordoas!

Mas toda anseio a vossa alma delira.

CORO DOS ANCIÃOS:

E amamo-las contudo.

A doçura da trança engrinaldada,

Do olhar de amor o precioso veludo,

Da sua voz a graça delicada!

Como as pequenas mãos sabem ornar

De frutas e de flores

Dos Deuses de oiro o luminoso altar!

Se são a dor, adormentam as dores.

Ó Káli, negra! Deusa ensanguentada, Há-de um corpo de amor cinzas ficar? 
CORO DAS MULHERES (trazendo todas as jóias de Sitá, o seu sari de noivado.

Vestem-na e enjóiam-na lentamente. Sitá, como num sonho, arranca e espalha uma a uma as suas flores da manhã:)

Ai! morre já, pobre amor!

Antes em cinzas ficar

Do que viveres na dor,

Que seres viúva, e durar

Ai de nós, pobres mulheres!

Damos vida e coração,

E dizem: prova, se queres,

Na morte a tua afeição.

Não foi a mãe a sorrir,

Quando éreis pequeninos,

Que vos ensinou a rir,

E a sonhar vergéis divinos?

Ai! e às vezes que travor

Se ocultava em nosso riso,

Quanta lágrima de dor

A iluminar um sorriso!

E em nós, esposas, não era

Em nós que vossa alma achava

Toda a luz da primavera.

Nós somos a alma escrava, 
O seio obscuro da Raça!

Ai! e é forçoso ocultar

Mocidade, encanto e graça,

E a sós connosco chorar.

Aves do céu,

Pobre flor

A mais humilde do chão,

Conheceis todas o amor,

Não sois desgraçadas, não.

Nos estames da sirissa

Vai poisar de leve a abelha.

A nós nunca em beijos viça

A nossa boca vermelha.

Chuvas do inverno! passais

Cobrindo a terra de flores.

Nossas lágrimas e ais

Só produzem desamores.

Adeus, Sitá! Vais bem linda

No teu sari de noivado.

Ditosa a mulher quefinda

Antes de um sonho acabado.

\section{A NAGAÍNA:}

Como a seda do pendão 
Que é contra o vento levado,

Segue o corpo, mas voltado

Para trás o coração.

( Todo o dia o sol responde e esmaga. Sitá jaz por terra no tchouki, ora desmaiada, ora com os olhos abertos e fixos, aprofundados pela febre. Tem todas as suas jóias como para um noivado.)

VOZES DA DLORESTA DE TECA E DE SADRÁS:

Sem uma folha ou flor, na chama que nos cresta.

Nem um grumo de seiva os nossos troncos nutre.

Só o trémulo grito estridente do abutre

Atravessa o esplendor e a mudez da floresta.

As raízes em vão na terra feita pedra

Tentam fugir na treva ao martírio da luz.

Ao lívido clarão dos céus já nada medra.

O orvalho não reanima os nossos ramos nus.

Em vão levanta aos céus a floresta os seus braços, Indefinidamente os desfolhados ramos...

Nos abismos de fogo e de luz dos espaços

Ninguém escuta! em vão, ó água! te imploramos.

Mais nos valera então como seca reina

Ardermos de repente em chamas e em perfume.

Absorve-nos a luz que deslumbra e alucina.

Nossa raíz é morta, a terra e o céu de lume. 
(As sombras caem a prumo. No Pagode da aldeia, diante do ĺdolo de resto negro e olhos de carbúnculos, o bhôto passa o candelabro ardente ou fumegante, oferencdo ao arthi do incenso, da luz e da cânfora em chama. Bailadeiras passeiam diante do Ídolo, em cadência lânguida.)

DJÂIÉÇERI (a bailadeira, canta, no ritmo dorido e trémulo do saranghi, e da murdanga:)

O amor é um instante apenas.

$E$ as almas enfim serenas

Vào cada qual seu caminho.

O desejo é sonho breve,

Desfaz-se num fogo leve.

Vem! Embriagda um carinho

Vamos desaparecer.

A flor antes de morrer

Num aroma se resume.

É só flor de vida o amor.

Vê! A minha boca é flor,

O meu sorriso perfume.

O amor é embriaguez ligeira,

Alegria passageira

Que adormenta para a morte.

São desejos os meus braços!

Vem! E ao abrirem-se lassos,

O sangue é mais doce e forte. 
CORO DAS BAILADEIRAS (numa coreia de evoluções mais rápidas:)

(Depois, de novo o silêncio do calor e da luz cai.)

VOZES DO BAMBUAL SEM FOLHAS:

Nenhuma aragem nos agita,

E trememos de febre e frio.

O ar também treme e palpita

Num calafrio.

Se à terra toda o céu escalda 
De luz e ardor,

Já sem uma folha de esmeralda,

A febre esfria-nos de dor.

Por todo o outeiro o ar tremula,

Como águas morytas freme, ondula,

Arde de febre como nós...

Crescem nas vestes cintilantes,

E falam sós,

Os Déussares de rosto preto.

Quem Ihes fixara os rostos hiantes,

Rostos de morto ou de esqueleto,

Turbilhonantes...

Ah! não encontras a tua porta,

Álevantina!

Ninguém quer ver entrar a morta,

E cair logo a casa em ruína.

Já te muraram essa porta,

Álveantina!

Passam, sozinhos, carros guiando

Por negros búfalos tirados...

Confusas línguas vão falando

De multidões, todas vozeando...

Bhuts, Mharus ensanguentados...

Dá-nos calor, ó sol! Escalda!

Nunca tão fria a terra esteve!

Nós já não temos a esmeralda

Da nossa folha clara e leve.

Mas negro o sol, negros os ares! 
Vamos tremer, morrer de frio...

Ah! como crescem os Déussares,

E o Sancalliô sobre do rio...

São negros, negros, e escarlates!...

É negro o ar, põem-no em sangue,

Em febre, a arder!... Febre! Não mates

O triste bambual exangue...

( $A$ tarde está a acabar.)

A PEQUENA SOMBRA BRANCA DA EURASIANA (esvoaça:)

Amei, fui feliz. Que importa

Que a vida fosse tão breve?

Como a terra é leve, leve,

Para o coração da morta!

A SOMBRA DE BÁRBARA ESCRAVA (na longa roupagem de musselina da noite:)
Amou-te
de amor
que une,
é Eva
da cor
da noite
llune,
o Poeta.

Amava

a Eva 
escrava.

Descansa,

ó Poeta!

na treva

da trança

preta.

Descansa

enfim

da dor

o Poeta,

assim

no ardor

de amor

da trança

preta.

AS RAIIZES DAS AVENCAS (nas paredes:)

Uma sede de água apenas!

E antes da morte, um momento,

Sentir nas floas serenas

Beijos da chuva e do vento.

AS RAÍZES DAS SELAGINELAS:

Sim, um só momento amar.

E depois secar, que importa!

Se fica o amor a velar

A pequena relva morta. 
CORO DO BULBUL E DO MURUÔNI:

Adeus, Sitá! Nunca mais

Nos tornaremos a ver.

Não mais farão nossos ais

A nossa amiga sofrer.

Porque há-de a afeição ligar,

Se é a vida esquecimento,

E há-de a saudade enlear

Quem morre a cada momento!

O que vale é que nós omos

Sonho que ilude e que falha,

E em breve tudo o que fomos

É poeira que o vento espalha.

Se o pó não se erguesse mais,

Se não fosse renascer!

Ai! oxalá que jamais

Nos não tornemos a ver.

(Um trovão ecoa. Sitá levanta-se, chorando silenciosamente.)

A NAGAÍNA (na meia obscuridade do pequeno altar do tulâsse, diz docemente:)

Fogem tão depressa os dias

Que nem chegamos a ver,

Se são os dias que morrem 
Ou nós que vamos morrer.

Hoje a vida que te importa,

Se a vida é amor, ilusão,

E agora o teu coração

É como se fosses morta.

É tão triste envelhecer!

Nova e linda é bem melho

Que o teu seio de mulher

Se funda em chama de amor.

O BHÔTHO (cantando a meia metalicamente os hinos da morte:)

Mahdeu! Mahdeu! Mahdeu!

Morreu com um olhar teu.

SITÁ ( soltando um grito, quebra umas contra as outras, erguendo ao alto os braços, as mulhas de esposa. Algumas gotas de sangue escorrem nos pulsos. Por fim arranca do pesqcoço o mourtámounim de casada:)

Sim, Nagaína, sim! aos céus vou procurar

O meu esposo amado, e o seus beijos de amor.

Perdoai todos vós os luto que vim dar.

Era nova, perdoai! não o soube guardar.

Adeus, ó mãe, ó pai! dir-lhe-ei vossa dor.

Minhas jóias, adeus! Meu sari de mulhe

No céu há-de soltá-lo o meu esposo agora.

Quem sabe quanta flor de luz hei-de ir colher! 
Ó flores que eu amei, nem uma só sequer

Meu leito enfeitará como eu sonhava outrora.

Amigas! Esquecei como eu era mazinha.

Mas nuca vos quis mal. Eu era uma criança,

Gostava só de rir! E vede a sina minha.

Bhôtho! corta depressa a minha pobre trança.

Sem manilhas, meu Deus! ter de sair sozinha.

(Sitá parte, encaminha-se para o jangal. A cobra-capelo segue-a. Cai a noite. Os relâmpagos incendeiam a sombra. A perder de vista a floresta anima-se de vagalumes. Caiu a noite)

CORO DOS OUTEIROS E DO JANGAL:

Sûrya, divino sol resplandecente,

Não podíamos mais de sede e ardor.

Tiveste compaixão da terra ardente, Arrebatada no imortal fulgor.

Graças, divino Sûrya! De repente

Foste ao céu de Indra em busca de outro amor,

E corou toda a tarde estranhamente

Das celestes Apsaras o rubor.

Dá um brilho de espadas o palmar.

Lança na Ihama da baía o luar, Um broquel de oiro fino martelado. 

A noite é um alvo lótus inclinado,
É um leve incenso lento sobre o mar,
E sobre a terra um sonho extasiado.

VOZES DA TERRA:

Nada sentir, não amar nem odiar!

Quem pudera ficar eternamente

Neste sonho da noite absortamente.

Não reflorir! nunca mais transmigrar!

O TIGRE REAL (acordando:)

Já fui Homem talvez... O meu dstino

É no sangue viver.

A noite é feita para o assassino

Não ver morrer.

Quem pudera passar entre as chitellas

Sem o sangue sentir,

E dos céus o rebanho das gazelas

Vem sem pena fugir.

Ah! não ver sangue, não ver

Olhos a agoniar!

Mahdeu! quando hei-de só ser a erva a germinar?

OS LÓTUS VERMELHOS:

No funod da água dormente

É tão doce desmaiar. 
E só vir num sonho ardente

Ao lume de água boiar.

\section{OS LÓTUS VERMELHOS:}

Um dia vieram amantes
A paz das águas buscar,
E ei-los ainda como antes

Os corações a sangrar

\section{OS LÓTUS BRANCOS:}

$E$ os sonhos que tinham dantes

Estão a desabrochar.

VOZES DAS RIBEIRAS (ao longe:)

Fugimos tão devagar

Para a noite, para o mar,

Para o deserto profundo...

Quem pudera descansar,

Não ter de recomeçar

O sofrimento no mundo!

(Sitá caminha sem ver, absorta, com a cabeça engrinaldada de flores da noite. Junto de uma fogueira breve um Asceta medita. Quando Sitá entra na clareira, vermelha de laterites, e negra de basaltos, o Mahatmã fixa-a longamente.)

\section{O MAHATMÃ:}

Foge de toda a ansiedade,

Pobre alma! A morte somente 
Pode de ti ter piedade,

Transmudar-te infindamente.

A NAGAÍNA:

Morrer, sofrer vagamente...

SITÁ (risonha e carinhosa:)

Diz, Sannyassi! não é certo que em breve

Ma há-de ele amar?

Que feita chama luminosa e leve

Me vai beijar?

O MAHATMÃ:

Sabes o que é o amor, saber o que é um beijo?

É ainda a dor, é ainda a inquietação

De nossa alma em procura de um ensejo

De se soltar so anseio e do desejo,

De encontrar paz na imensa agitação!

\section{A NAGAIINA:}

Deixa-o, Sitá, falar! já ignora a paixão, Já não conhece o amor.

Vida, beleza, amor, é somente a ilusão

A disfcarçar a dor...

Mas que te importa a dor, se tu tens a ilusão!

O MAHATMÃ:

Se crês que queres mais, pobre alma! que a ilusão? 
(Sitá, surpreendida, olha ora o Mahatmã, ora a Nagaína. Com os pés espalha nervosamente a fogueira do Asceta sobre o capim seco e as folhas mortas. $O$ incêndio ateia-se no jàngal.)

SITÁ (indicando a cobra-capelo:)

Ó Mahatmã! és como ela impostor?

O MAHATMÃ (murmura num êxtase:)

Não crer! Rasgar enfim a venda da ilusão!

A NAGAÍNA (silva:)

Saber! Enfim romper a miragem da dor!

SITÁ (entrando no incêndio:)

Eu já te vejo, Esposo amado, todo amor, Em meu seio, amor meu...

(a sua voz, perdendo-se:)

Ó meu amor, ó meu amor! no céu...

(O raio estala. Toda a floresta é um esbraseamento na noite. Ao vir de alva, nas cinzas do Jangal, sobre a terra vermelha de Hind, as flores germinam com a primeira chuva.) 


\section{Bibliografia}

ARNOLD, Edward Vernon. Vedic Metre: in its historical development. - Cambridge: University Press, 1905.

BAJU, Anatole. Manifesto SImbolista. In: TELES, Gilberto de Mendonça. Vanguardas Europeias e Modernismo Brasileiro - Petrópolis: Editora Vozes, 1997.

BALAKIAN, Ana. O Simbolismo. São Paulo: Perspectiva, 2007. 
BHABHA, Homi K. O local da cultura. - Belo Horizonte: Ed. UFMG, 2010.

BERNARDO, Maria Celeste da Silva. Alberto Osório de Castro, o homem, o escritor, a obra. Lisboa, 1971.

BOSI, Alfredo. História concisa da literatura brasileira. São Paulo: Cultrix, 2003.

BUCK, William. O Ramayana: O clássico poema épico indiano recontado em prosa por William Buck. Trad. Octavio Mendes Cajado - São Paulo: Editora Cultrix, 2011.

CANDIDO, Antonio. O estudo analítico do poema. - São Paulo: Terceira Leitura, FFLCH USP, 1993.

CASTRO, Alberto Osório de. Camilo Pessanha em Macau. In: LANCASTRE, Maria José de. Camilo Pessanha, cartas a Alberto Osório de Castro, João Baptista de Castro e Ana de Castro Osório. - Lisboa: Imprensa Nacional Casa da Moeda, 1984.

CASTRO, Alberto Osório de. De Paris. In: Bohemia Nova. Ano 1, n 2, 15 de Fevereiro de 1889.

CASTRO, Alberto Osório de. Palestra com Dr. Topsius. In: Bohemia Nova. Ano 1, n 5, 22 de Março de 1889, p.7.

CASTRO, Alberto Osório de. A ilha verde e vermelha de Timor. Lisboa: Edições Cotovia, 1996.

CASTRO, Eugénio de. Oaristos In. VOUGA, Vera (org.). Obras poéticas de Eugênio de Castro - Porto: Campo das Letras, 2001.

CRUZ, Duarte Ivo. Introdução à história do teatro português. Lisboa: Guimarães e Cia. Editores, 1983.

DEVI, Vimala e SEABRA, Manuel. A literatura indo-portuguesa, Parte I. - Lisboa: Junta de Investigações do Ultramar, 1971.

FERNANDES, Agostinho. Bodki. In: DEVI,Vimala \& SEABRA, Manuel. A Literatura IndoPortuguesa. - Lisboa: Junta de Investigações do Ultramar, 1971.

GRACIAS, F. S. The many faces of Sundore: Women in Goa. Panjim: Surya Publications, 2007. 
GUMARÃES, Fernando. Simbolismo, Modernismo e Vanguardas. - Lisboa: Imprensa Nacional Casa da Moeda, 1982.

MACHADO, Álvaro Manuel. O mito do Oriente na literatura portuguesa. Lisboa: Instituto de Cultura e Língua Portuguesa.

MELLO, Leonel Itaussu A. e COSTA, Luís César Amad. História Moderna e Contemporânea. São Paulo: Scipione, 1999.

MORÉAS, Jean. Manifesto Simbolista. In: TELLES, G.M. (org.) Vanguarda européia e modernismo brasileiro - Petrópolis: Editora Vozes, 1997.

OLIVEIRA, Ana Maria da Conceição. Alberto Osório de Castro, ensaio bio-bibliográfico e crítico. Lisboa, 1959.

PEREIRA, José Carlos Seabra. Decadentismo e simbolismo na poesia portuguesa. Coimbra, 1975.

ROMAN, E. N. Aparições de Nossa Senhora e suas mensagens e milagres. São Paulo: Paulus, 2012.

SAID, Edward W. Orientalismo: O Oriente como invenção do Ocidente. - São Paulo: Companhia das Letras, 2007.

TELLES, Gilberto de Mendonça. Vanguarda Europeia e Modernismo Brasileiro. Petrópolis: Editora Vozes, 1997.

VERNE, Julio. A volta ao mundo em oitenta dias. Trad. Antonio Caruccio-Caporale. - Porto Alegre: L\&PM, 2010.

ZIMMER, H. Mitos e símbolos na arte e civilização da Índia. São Paulo: Editora Palas Atena, 1989. 